\title{
Cellular prion protein inhibits proapoptotic Bax conformational change in human neurons and in breast carcinoma MCF-7 cells
}

\author{
X Roucou ${ }^{1,4}$, PN Giannopoulos ${ }^{1}$, Y Zhang ${ }^{1,2}$, J Jodoin ${ }^{1,2}$, \\ CG Goodyer $^{3}$ and A LeBlanc ${ }^{\star, 1,2}$ \\ 1 The Bloomfield Center for Research in Aging, Lady Davis Institute for Medical \\ Research, The Sir Mortimer B Davis Jewish General Hospital, Montréal, \\ Québec, Canada \\ 2 Department of Neurology and Neurosurgery, McGill University, Montréal, \\ Canada \\ 3 Department of Pediatrics, McGill University, Montréal, Canada \\ ${ }^{4}$ Current address: Department of Biochemistry, Faculty of Medicine, \\ Sherbrooke University, Sherbrooke, Canada \\ * Corresponding author: A LeBlanc, The Bloomfield Center for Research in \\ Aging, Lady Davis Institute for Medical Research, The Sir Mortimer B Davis \\ Jewish, General Hospital, 3755 Ch. Côte Ste-Catherine, Montréal, Québec, \\ Canada H3T 1E2. Tel: 514-340-8260; Fax: 514-340-8295; \\ E-mail: andrea.leblanc@mcgill.ca
}

Received 11.10.04; revised 04.2.05; accepted 03.3.05; published online 22.4.05 Edited by JC Martinou

\begin{abstract}
Prion protein (PrP) prevents Bcl-2-associated protein X (Bax)mediated cell death, but the step at which PrP inhibits is not known. We first show that PrP is very specific for Bax and cannot prevent Bak (Bcl-2 antagonist killer 1)-, tBid-, staurosporine- or thapsigargin-mediated cell death. As Bax activation involves Bax conformational change, mitochondrial translocation, cytochrome $c$ release and caspase activation, we investigated which of these events was inhibited by PrP. PrP inhibits Bax conformational change, cytochrome $c$ release and cell death in human primary neurons and MCF-7 cells. Serum deprivation-induced Bax conformational change is more rapid in PrP-null cells. PrP does not prevent active caspase-mediated cell death. PrP does not colocalize with Bax in normal or apoptotic primary neurons and cannot prevent Bax-mediated cytochrome $c$ release in a mitochondrial cell-free system. We conclude that PrP protects against Bax-mediated cell death by preventing the Bax proapoptotic conformational change that occurs initially in Bax activation. Cell Death and Differentiation (2005) 12, 783-795.

doi:10.1038/sj.cdd. 4401629

Published online 22 April 2005
\end{abstract}

Keywords: prion protein; Bax; apoptosis; human primary neurons; MCF-7; cytochrome $c$

Abbreviations: AIF, apoptosis-inducing factor; Bak, Bcl-2 antagonist killer 1; Bax, Bcl-2-associated protein X; BAR, bifunctional apoptosis regulator; $\mathrm{Bid}, \mathrm{BH} 3$-interacting domain death agonist; BI-1, Bax inhibitor I; CHAPS, 3-[(3-cholamydopropyl)dimethylammonio]-2-hydroxy-1-propanesulfonic acid; DTR, Dextran Texas Red; $\mathrm{mtHsp70,} \mathrm{mitochondrial} \mathrm{Hsp70} \mathrm{protein;} \mathrm{NP-40,}$ nonidet P-40; PrP, prion protein; STS, staurosporine; tBid, truncated Bid

\section{Introduction}

While the nature of infectious prion protein (PrP) has been intensively investigated, the function of normal cellular PrP is yet to be entirely resolved. In many instances, PrP acts as a neuroprotective or survival protein. PrP-null cells are more susceptible to serum deprivation and oxidative stress than PrP-expressing cells. ${ }^{1,2}$ PrP prevents anisomycin-mediated cell death in the neuroblastic layer of mouse retinal explants, ${ }^{3,4}$ Doppel- and $\mathrm{N}$-terminally truncated PrP-induced neurodegeneration in mice, ${ }^{5,6}$ and tumor necrosis factor $\alpha$ (TNF $\alpha$ )-induced apoptosis in MCF-7 cells. ${ }^{7}$ We have shown that both wild-type and cytosolic PrP completely inhibit Bcl-2associated protein $X$ (Bax)-mediated cell death in human neurons in primary cultures. ${ }^{8,9}$ However, whether PrP inhibits upstream or downstream of Bax activation is not known.

Bax is a major proapoptotic protein of neuronal cells. ${ }^{10,11}$ In normal conditions, Bax is monomeric and is either cytosolic or loosely attached to the mitochondrial outer membrane. ${ }^{12}$ Following a proapoptotic stimulus, Bax translocates from the cytosol to the mitochondria, changes conformation to expose its $\mathrm{N}$-terminal domain and oligomerizes at the mitochondria. These events, conveniently labeled Bax activation, result in the release of mitochondrial apoptogenic proteins including cytochrome c, endonuclease G, Smac/Siablo, Htr2/Omi and apoptosis-inducing factor (AIF), which activate caspasedependent and -independent apoptosis pathways. ${ }^{13} \mathrm{Bcl}-2$, $\mathrm{Bcl}-\mathrm{xL}, \mathrm{Ku} 70$, Bax inhibitor 1 (BI-1), bifunctional apoptosis regulator (BAR), humanin, $\mathrm{Hsp} 70, \alpha \mathrm{A}$ - and $\alpha \mathrm{B}$-crystallins and nonphosphorylated 14-3-3 protein have been identified as natural Bax inhibitors. ${ }^{14-22}$ All of these except BAR and BI-1 are cytosolic and directly interact with Bax. All, except Bcl-2, and BAR, have been shown to prevent Bax translocation to the mitochondria. $\mathrm{Bcl}-2, \mathrm{Bcl}-\mathrm{xL}, \mathrm{BI}-1$, and $\mathrm{Ku} 70$ proteins have also been shown to prevent Bax proapoptotic conformational change. BAR and $\mathrm{Bl}-1$ are endoplasmic reticulum (ER) transmembrane proteins that interact with $\mathrm{Bcl}-2$ but not Bax, and their effect on Bax conformational change or translocation is unclear at this time.

In this study, we investigate the step at which PrP inhibits Bax-mediated cell death in human neurons. We find that PrP protection is fairly specific to Bax since PrP does not protect against Bcl-2 antagonist killer 1- (Bak), truncated Bid- (tBid), staurosporine- (STS) and thapsigargin-mediated cell death. 
Using subcellular fractionation and gel filtration chromatography, we confirm that Bax undergoes a conformational change and oligomerization in apoptotic primary human neurons. In parallel with inhibition of cell death, PrP inhibits $6 \mathrm{~A} 7$ antibodypositive Bax conformational change in human neurons and in breast cancer MCF-7 cells microinjected or transfected with Bax or EGFP-Bax cDNA overexpression constructs to simulate specific Bax proapoptotic activation. Furthermore, Bax conformational change occurs more rapidly in serumdeprived immortalized hippocampal PrP-null cells than in the PrP-expressing counterparts. PrP does not prevent EGFP-Bax mitochondrial localization in human neurons, but partially inhibits mitochondrial EGFP-Bax translocation in MCF-7 cells. PrP prevents Bax-mediated cytochrome $c$ release in neurons and MCF-7 cells. However, recombinant PrP (R-PrP), unlike Bcl-2, cannot prevent Bax-mediated cytochrome $c$ release from purified mitochondria in a cell-free assay. In addition, PrP does not prevent human neuronal cell death after the activation of the effector caspase. We conclude that PrP prevents Bax-mediated cell death by inhibiting the very first step of Bax proapoptotic activation, and that PrP does not function exactly like Bcl-2 despite strong functional similarities with $\mathrm{Bcl}-2$. These results unexpectedly add $\operatorname{PrP}$ to the growing list of Bax inhibitors and caution against the ablation of the prnp gene as a method to eradicate infectious PrP diseases.

\section{Results}

\section{PrP prevents Bax but not Bak- or tBid-mediated cell death in human neurons and MCF-7 cells}

We have previously shown that PrP prevents Bax-mediated cell death in human neurons. ${ }^{8,9}$ To assess the specificity of this neuroprotective role for PrP against Bax, we investigated if $\operatorname{PrP}$ could prevent cell death due to Bak, another proapoptotic member of the $\mathrm{Bcl}-2$ family that is closely related to Bax. ${ }^{23,24} \mathrm{PrP}$ does not prevent EGFP-Bak-mediated cell death in human neurons (Figure 1a). To determine if the antiBax function of PrP is specific to human neurons, we studied MCF-7 cells, where PrP was found to protect against TNF $\alpha$ induced cell death. ${ }^{7}$ PrP maintains its protection against Baxmediated cell death in the MCF-7 cells as does Bcl-2, allowing us to use these as a model cell line to study the effects of PrP (Figure 1b). We then investigated if PrP could prevent cell death mediated by $\mathrm{tBid}$, a $\mathrm{BH} 3-o n l y$ proapoptotic $\mathrm{Bcl}-2$ protein that activates both Bax and Bak. ${ }^{25,26}$ In human neurons, PrP does not prevent tBid-DsRed2-mediated cell death (Figure 1c), but partially protects MCF-7 cells (Figure 1d). This partial protection can be explained by the fact that EGFPBak does not cause rapid cell death in MCF-7 cells (Figure 1e). Indeed, PrP does not protect anymore in MCF7 cells 48 or $96 \mathrm{~h}$ after tBid-DsRed2 transfection (Figure 1d).
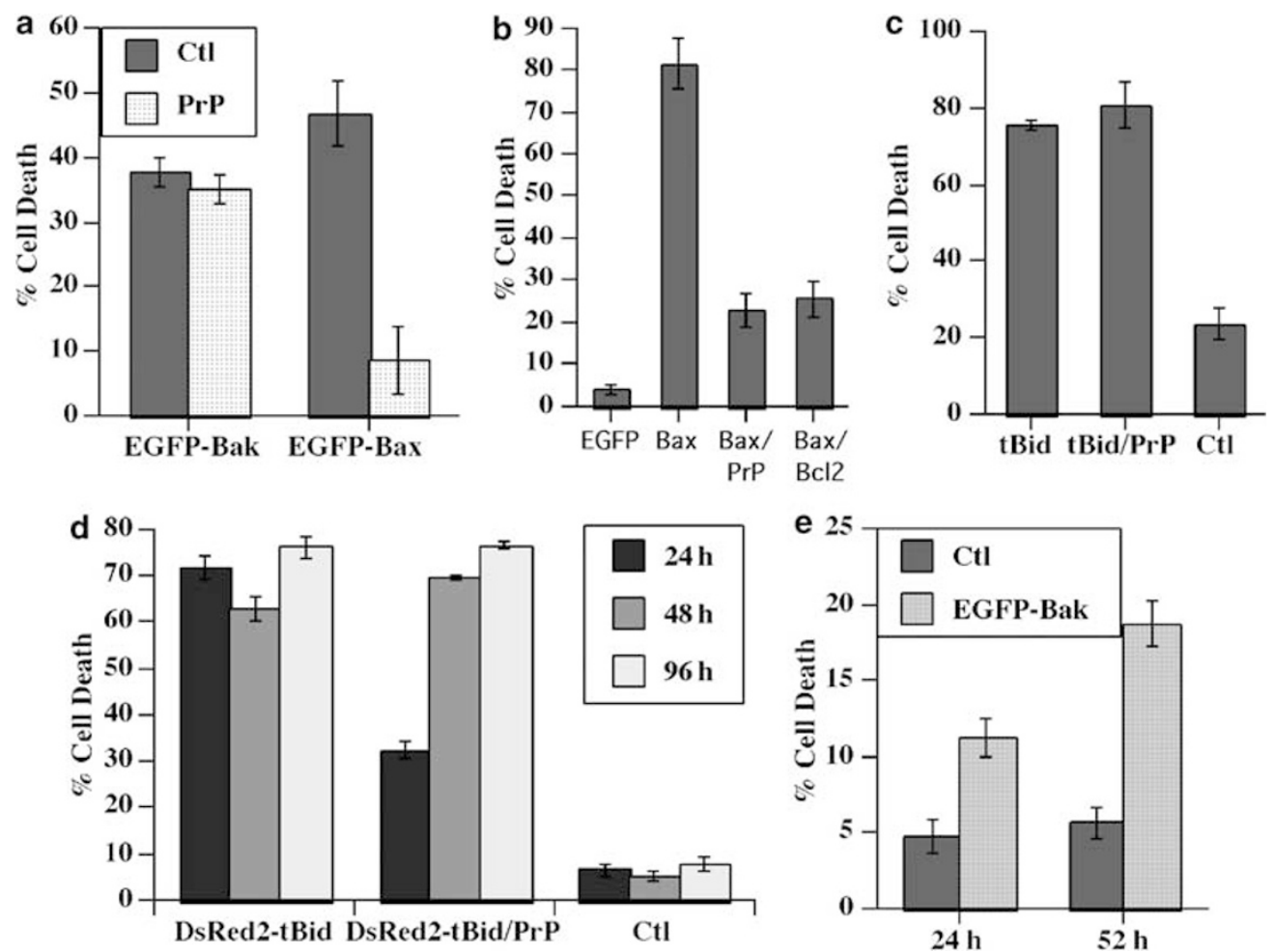

Figure 1 PrP prevents Bax-mediated cell death but not tBid- or Bak-mediated apoptosis. (a) TUNEL-positive neuronal cell death in pCep4 $\beta$ (Ctl)- or pCep4 $\beta$-EGFPBax- or pCep4 $\beta$-EGFP-Bak-microinjected cells (24h). (b) Cell death in MCF-7 cells transfected with pCep4 $\beta$-EGFP, pCep4 $\beta$-Bax (Bax), pCep4 $\beta$-Bax + pCep4 $\beta$-PrP $(\mathrm{Bax} / \mathrm{PrP})$ or pCep4 $\beta$-Bax $+\mathrm{pCep} 4 \beta$-Bcl2 (Bax/Bcl2) for $24 \mathrm{~h}$. (c) Cell death in human neurons transfected with pCep4 $\beta$-tBid-DsRed2 (tBid), pCep4 $\beta$-tBidDsRed2 + pCep4 $\beta$-PrP (tBid/PrP) or pCep4 $\beta$ (Ctl) for $24 \mathrm{~h}$. (d) Cell death in MCF-7 cells transfected with pCep4 $\beta$-tBid-DsRed2, pCep4 $\beta$-tBid-DsRed2 + pCep4 $\beta$-PrP or pCep $4 \beta$ (Ctl) for 24,48 and $96 \mathrm{~h}$. (e) Cell death in MCF-7 cells transfected with pCep4 $\beta$-EGFP-Bak or pCep4 $\beta$ (Ctl) for 24 and $52 \mathrm{~h}$ 
Together, these results show that PrP protection is fairly specific to Bax, but can occur in both terminally differentiated and in cycling cell types.

\section{Bax undergoes mitochondrial translocation, oligomerization and induces the release of cytochrome $c$ in STS-induced apoptotic human neurons}

Bax-mediated cell death occurs through a series of wellcontrolled steps, which include a conformational change that exposes the $\mathrm{N}$ - and $\mathrm{C}$-termini of Bax, oligomerization of Bax and translocation from cytosol to the mitochondria, resulting in the release of cytochrome $c$ and caspase activation. Inhibition of any of these events would result in protection against Baxmediated cell death. We set out to investigate which of these steps PrP inhibited. We first verified the series of events involved in Bax-mediated cell death in primary cultures of human neurons because mechanisms of cell death are sometimes different in this cell type. ${ }^{27-29}$ In normal nonapoptotic conditions, Bax is more abundant in the cytosol of human neurons, but a certain amount copurifies with mitochondria (Figure 2a and c). As in other cells, cytosolic monomeric Bax translocates to the mitochondria (Figure 2a), undergoes the 6A7 antibody-positive conformational change (Figure $2 \mathrm{~b}),{ }^{30}$ oligomerizes at the mitochondria (Figure $\left.2 \mathrm{c}\right),{ }^{31}$ and induces the release of cytochrome $c$ (Figure $2 \mathrm{~d})^{21}$ in STStreated apoptotic neurons. Immunoprecipitation of a small amount of Bax with the 6A7 antibody (Figure 2b) and the presence of cytosolic cytochrome $c$ in normal neurons (Figure 2d) indicates a low level of Bax activation that likely results from damage of the neuritic network during subcellular fractionation of the neurons under native condi- tions since activated Bax could not be detected in neuronal cultures by immunofluorescence (Figure 3a). These results show that Bax activation occurs normally in apoptotic human neurons.

\section{PrP prevents Bax conformational change in neurons}

To investigate if PrP can prevent Bax conformational change, neurons were microinjected with human Bax cDNA expressed under the strong cytomegaloviral promoter to induce specific Bax-mediated cell death, ${ }^{8}$ and immunostained with the 2D2 or $6 \mathrm{~A} 7$ antibodies that detect total Bax and apoptotic Bax, respectively. The 2D2 antibody detects Bax in all neurons (Figure 3a). In contrast, the 6A7 proapoptotic Bax antibody immunostains Bax-injected neurons only, indicating conformational change following overexpression of Bax. Neurons coinjected with Bax and PrP or Bax and Bcl-2 cDNAs fail to show immunoreactivity to $6 A 7$, while $2 \mathrm{D} 2$ immunoreactivity is preserved. A higher magnification view of the microinjected cells shows that 6A7- and 2D2-positive Bax is abundantly cytosolic (Figure 3a lower panel presented as merge of figure insets) as seen in other cell types. ${ }^{32}$ As the Dextran Texas Red (DTR) comicroinjected to mark the injected cells aggregates, it is very difficult to colocalize Bax with specific organelles, but the punctate appearance of some of the immunostaining indicates a possible mitochondrial localization. We conclude from this experiment that, like Bcl-2, PrP prevents Bax conformational proapoptotic change in primary human neurons.

Human neurons are difficult to transfect and microinjections limit the studies to single-cell analysis. Therefore, we tested the ability of endogenous PrP to prevent apoptotic Bax

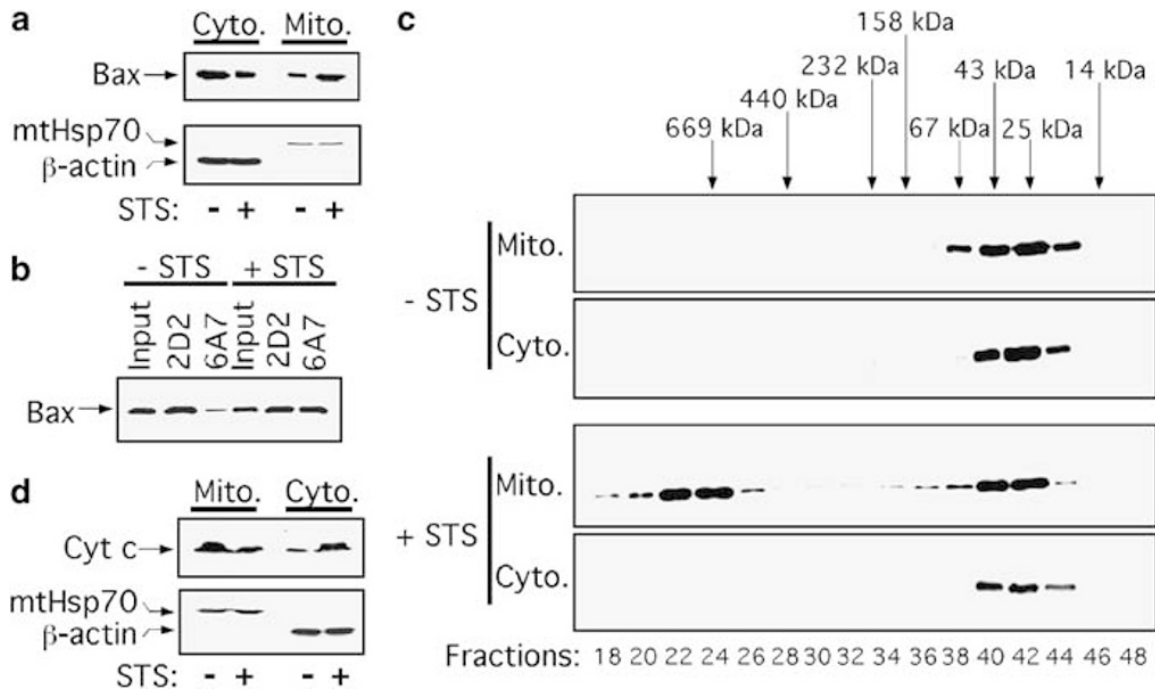

Figure 2 Bax undergoes translocation, conformational change, oligomerization and induces the release of cytochrome $c$ in apoptotic human neurons. (a) Western blot analysis of (a) cytosolic (cyto.) and mitochondrial (mito.) proteins from DMSO-treated (-STS) or $0.5 \mu \mathrm{M}$ STS-treated ( + STS) neurons with the polyclonal N20 anti-Bax, and monoclonal mtHsp70 and $\beta$-actin antibodies. (b) Monoclonal 2D2- (total Bax) or 6A7- (proapoptotic Bax) immunoprecipitated Bax from CHAPS lysates of DMSOtreated (-STS) or STS-treated ( + STS) neurons with anti-N20 antisera. Input represents $20 \%$ of total lysate before immunoprecipitation. (c) Western blot analysis of Bax after size exclusion chromatography of mitochondrial (mito.) or cytosolic (cyto.) proteins with the 2D2 antibody. Calibration molecular weights are indicated on top. The analysis was conducted every second fraction of the gel filtration as indicated on the bottom. (d) Western blot analysis of cytochrome $c$, $\mathrm{mtHsp} 70$ and $\beta$-actin in the mitochondrial (mito.) and cytosolic (cyto.) proteins of -STS- or + STS-treated neurons 
a

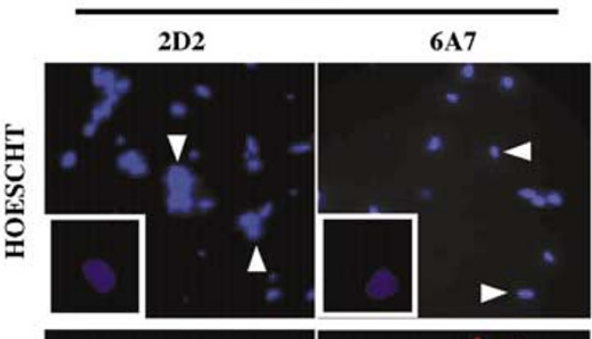

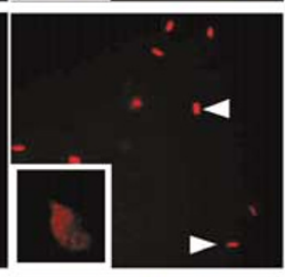
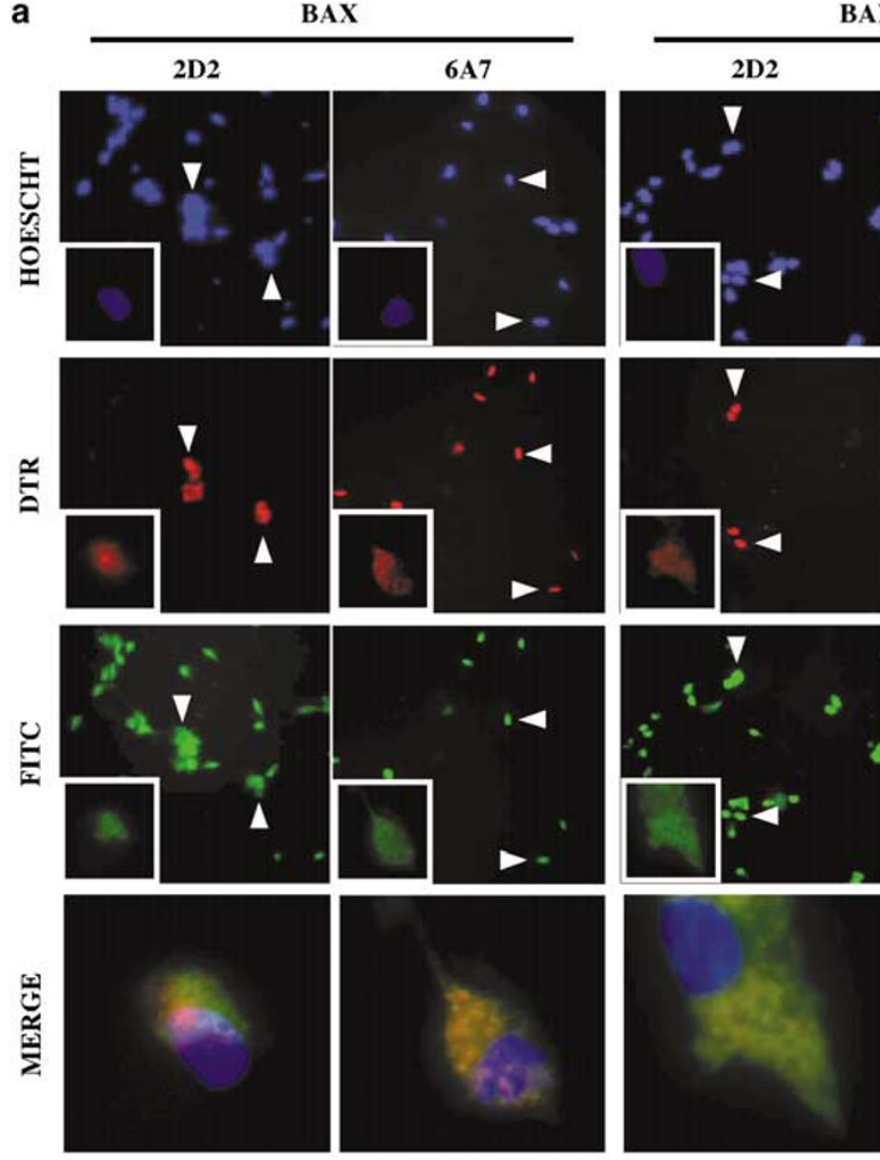

BAX/PrP

BAX/Bcl-2
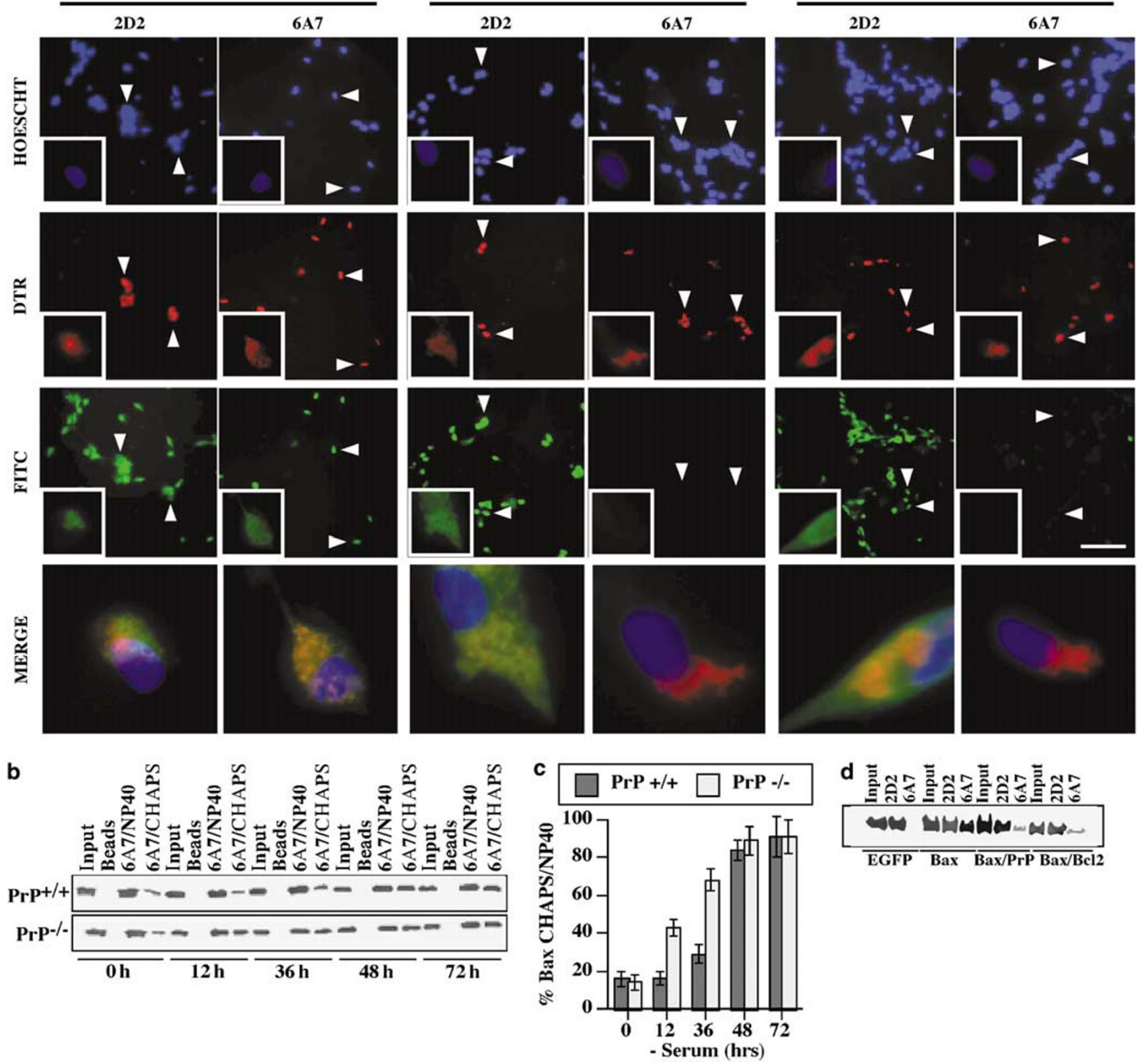

Figure 3 PrP prevents Bax conformational change in several cell types. (a) Immunostaining of total Bax with 2D2 and proapoptotic Bax with 6 A7 in human primary neurons microinjected with a cDNA construct expressing Bax or coinjected with cDNAs expressing Bax and PrP or Bax and Bcl-2. Nuclei were stained with Hoescht. DTR-positive cells represent injected neurons. Secondary antibodies were conjugated with FITC. Insets show high magnification of an injected neuron and these are magnified and merged in the last row. Arrows indicate examples of injected neurons. Similar results were observed in two independent neuronal preparations. Magnification $\times 20(\times 100$ in insets). Bar is $100 \mu \mathrm{m}$. (b) Polyclonal N20 antibody Western blot analysis of Bax immunoprecipitated with monoclonal 6 A7 antibody in NP40 or CHAPS protein extracts from mouse HW3-5 (PrP ${ }^{+/+}$) and $\mathrm{HpL}^{-4} 4$ (PrP ${ }^{-1-}$ ) neuronal cells after serum deprivation for $0-72 \mathrm{~h}^{-}$Input represents $20 \%$ of total lysate before immunoprecipitation. Beads represent immunoprecipitation carried out with Sepharose beads in the absence of $6 A 7$ antibody. (c) Densitometric analysis of Bax immunoprecipitated from mouse HW3-5 ( $\left.\mathrm{PrP}^{+I+}\right)$ and $\mathrm{HpL}^{-4}\left(\mathrm{PrP}^{-I-}\right)$ neuronal cells. Arbitrary densitometric values of Bax immunoprecipitated in $\mathrm{CHAPS}$ buffer are normalized to arbitrary densitometric values of Bax immunoprecipitated in NP40 buffer (mean \pm S.D., $n=3$ ). ${ }^{\star} P<0.02$ in $\mathrm{HpL} 3-4$ (PrP ${ }^{-1-}$ ) compared to HW3-5 (PrP ${ }^{+1+}$ ). (d) Polyclonal N20 antibody Western blot analysis of Bax immunoprecipitated with 2D2 and 6A7 antibodies in CHAPS protein extracts from MCF-7 cells $24 \mathrm{~h}$ posttransfection with pCep $4 \beta$ cDNAs expressing EGFP, Bax, Bax and PrP, or Bax and Bcl-2. Input represents $20 \%$ of total lysate before immunoprecipitation

conformational change in mouse $\mathrm{PrP}^{+1+}$ and $\mathrm{PrP}^{-1-}$ hippocampal and MCF-7 cell lines. $\mathrm{PrP}^{-1-} \mathrm{HpL3}-4$ cells are more sensitive to serum deprivation than $\mathrm{PrP}^{+1+} \mathrm{HW} 3-5$ cells and are rescued by overexpression of $\mathrm{PrP}$ or $\mathrm{Bcl}-2$ indicating that serum-deprived cell death might occur through
Bax activation. ${ }^{1}$ Nonidet P-40 (NP-40) is used as a positive control for $6 \mathrm{~A} 7$ because it artificially induces Bax conformational change. ${ }^{30}$ The $6 A 7$ antibody immunoprecipitates slightly less Bax in serum-deprived neurons lysed with NP40 detergent, indicating that total levels of Bax decrease 
slightly after serum deprivation (Figure 3b). However, the amount of 6A7-positive Bax is considerably higher in both serum-deprived cell lines indicating Bax activation. Within 12$36 \mathrm{~h}$ of serum deprivation, there is more than twice the amount of $6 \mathrm{~A} 7$ immunoprecipitated Bax in $\mathrm{PrP}^{-1-}$ than $\mathrm{PrP}^{+/+}$cells (Figure $3 \mathrm{~b}$ and $\mathrm{c}$ ). After 48 and $72 \mathrm{~h}$ of serum deprivation, the amount of Bax that has changed conformation is similar in both cell lines, as expected in the presence of a continuous insult. Similarly, PrP prevents Bax conformational change induced by Bax overexpression in MCF-7 cells since there is a significant decrease in the amount of 6A7-immunoprecipitable Bax in PrP-transfected cells (Figure $3 d$ ). These results show that PrP delays Bax conformational change induced by either serum deprivation or overexpression of Bax in primary human neurons, immortalized mouse hippocampal neurons and in the breast carcinoma MCF-7 cell line.

\section{PrP prevents Bax-mediated cytochrome $c$ release in human neurons and MCF-7 cells}

$\mathrm{Bcl}-2$ has been shown to prevent Bax-mediated cell death without affecting cytochrome $c$ release in transfected
HEK293T cells. ${ }^{33}$ To determine if PrP prevents Bax-mediated mitochondrial cytochrome $c$ release, human neurons were transfected with EGFP-Bax cDNA and immunostained with anti-cytochrome $c$ antibodies (Figure $4 \mathrm{a}$ and Supplementary Figure S1). Neurons transfected with EGFP alone display diffuse fluorescence consistent with cytosolic and nuclear localization of EGFP (Figure 4a). EGFP-Bax localizes mainly at the mitochondria and induces the loss of mitochondrial cytochrome $c$ immunostaining (Figure 4a). Diffuse cytosolic cytochrome $c$ is generally not detected in neurons. ${ }^{34,35}$ However, when PrP or Bcl-2 is cotransfected with EGFPBax, cytochrome $c$ is easily detected (Figure 4a). MCF-7 cells expressing EGFP display normal nuclei, diffuse EGFP fluorescence and mitochondrial cytochrome $c$ (Figure $4 \mathrm{~b}$ and Supplementary Figure S2). In contrast, cells expressing EGFP-Bax have condensed nuclei and punctate mitochondrial EGFP-Bax fluorescence, and cytochrome $c$ is not detected in these cells. Coexpression of EGFP-Bax with PrP or Bcl-2 cDNAs inhibits cytochrome $c$ release. Quantitative analysis indicates that EGFP-Bax induces the release of cytochrome $c$ in over $90 \%$ of neurons and MCF-7 cells. PrP and $\mathrm{Bcl}-2$ prevent EGFP-Bax-induced cytochrome $c$ release in around $80 \%$ of cells (Figure $4 \mathrm{c}$ ). These results indicate that a
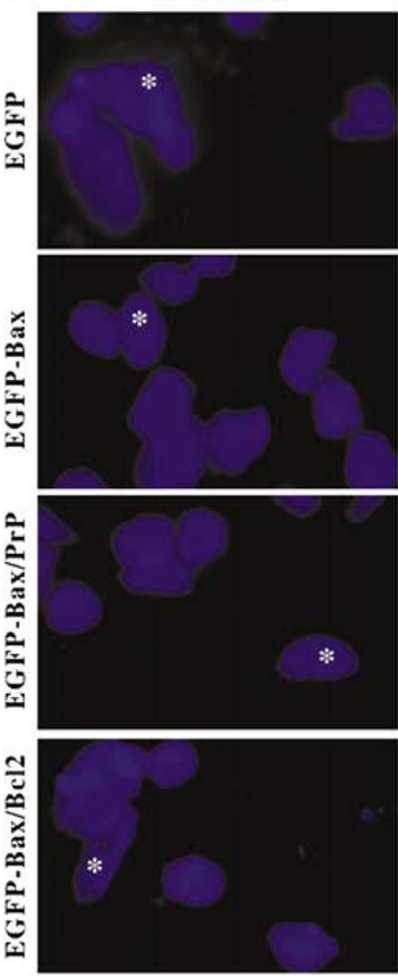

EGFP
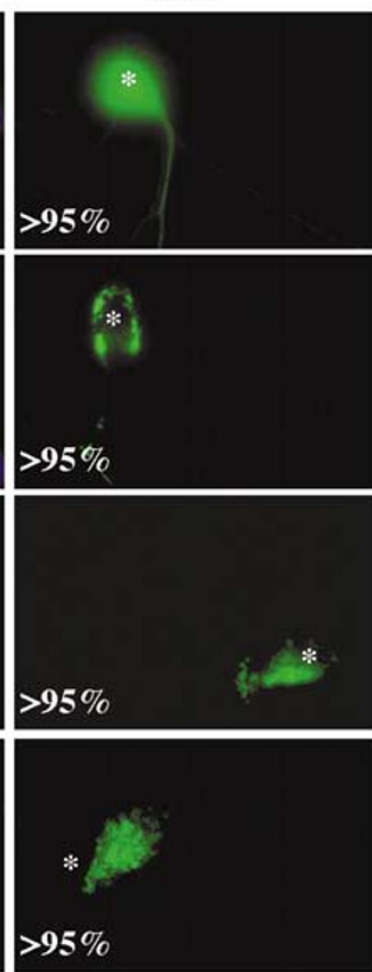

Cyt. c
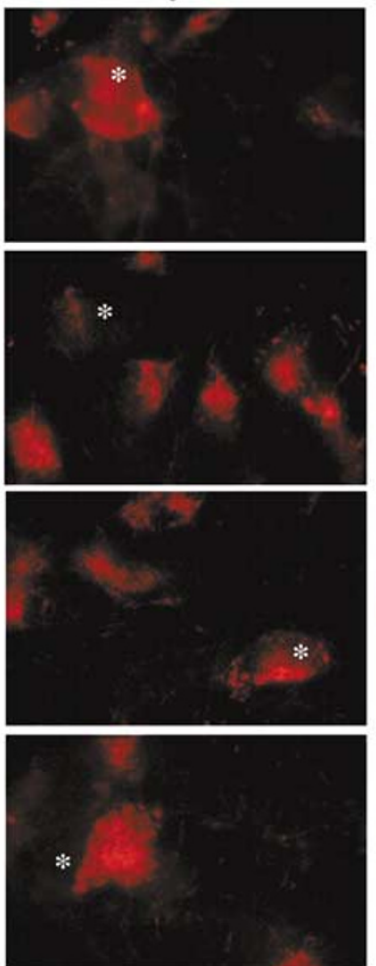
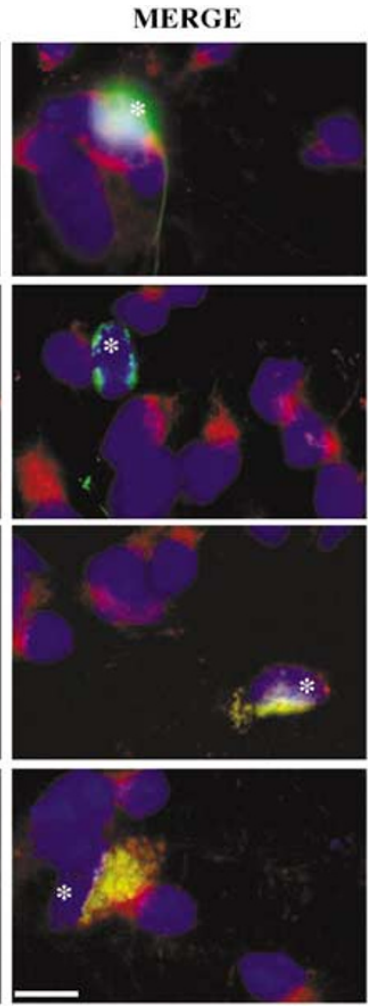

Figure 4 PrP prevents Bax-mediated cytochrome $c$ release in human neurons and MCF-7 cells. (a) Immunocytochemical analysis of cytochrome $c$ (Cyt. $c$ ) in human neurons transfected with pBud constructs expressing EGFP, EGFP-Bax, EGFP-Bax and PrP, or EGFP-Bax and Bcl-2. The three channels are shown separately as nuclear Hoescht stain, EGFP, Cyt. $c$, and merged. Similar results were observed in four independent neuronal preparations. Magnification $\times 60$. Bar is $25 \mu$ m. (b) Cytochrome $c$ immunostaining in MCF-7 cells transfected as described in (a). Similar results were observed in three independent experiments. Magnification $\times 60$. Bar is $25 \mu \mathrm{m}$. For (a) and (b), asterisks indicate transfected cells and numbers indicate the percentage of cells with the same pattern of EGFP or EGFP-Bax distribution. (c) Percentage of cells with released cytochrome $c$ transfected as described in (a) and (b). More than 80 neurons and 200 MCF-7 cells were counted for each condition. (d) Western blot analysis of Bax with the anti-N20 antisera in lysate, mitochondria (Mito.), cytosol (Cyto.) and microsomes (Micro.) from DMSO-treated (-STS) or STStreated (+ STS) MCF-7 cells, or Bax-, and EGFP-Bax-transfected MCF-7 cells. (e) Western Blot analysis of cytochrome $c$ and mtHsp70 in mitochondrial and cytosolic proteins of mock-, Bax-, and Bax- and PrP-pCep4 $\beta$-transfected MCF-7 cells 
788
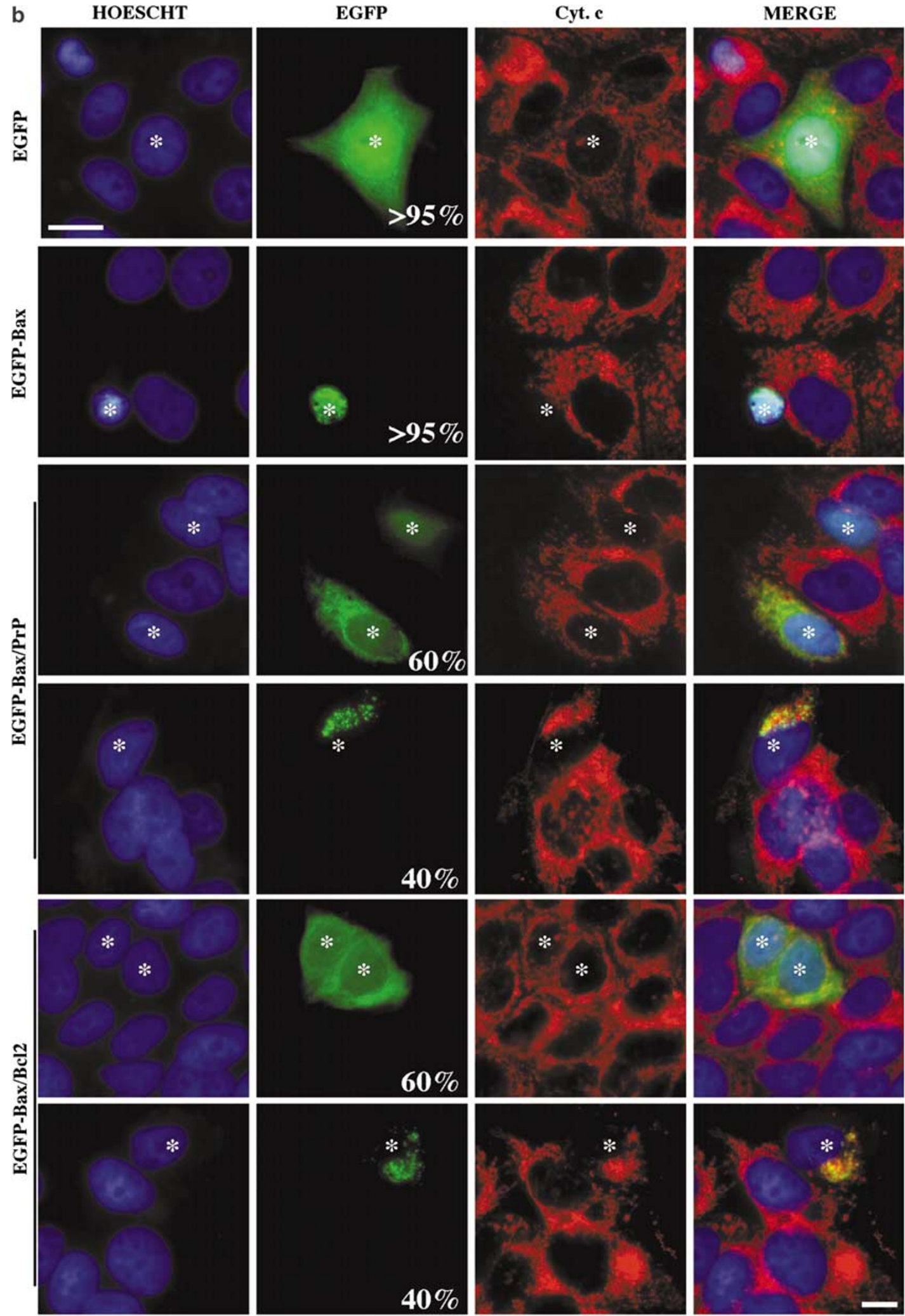

Figure 4 Continued

PrP's inhibition of 6A7-positive Bax conformational change prevents Bax-mediated cytochrome $c$ release in human neurons and in MCF-7 cells.
To assess if EGFP-Bax can be compared to Bax overexpression, MCF-7 cells were transfected with empty vector, nontagged Bax or EGFP-Bax. The vector-transfected cells 
C
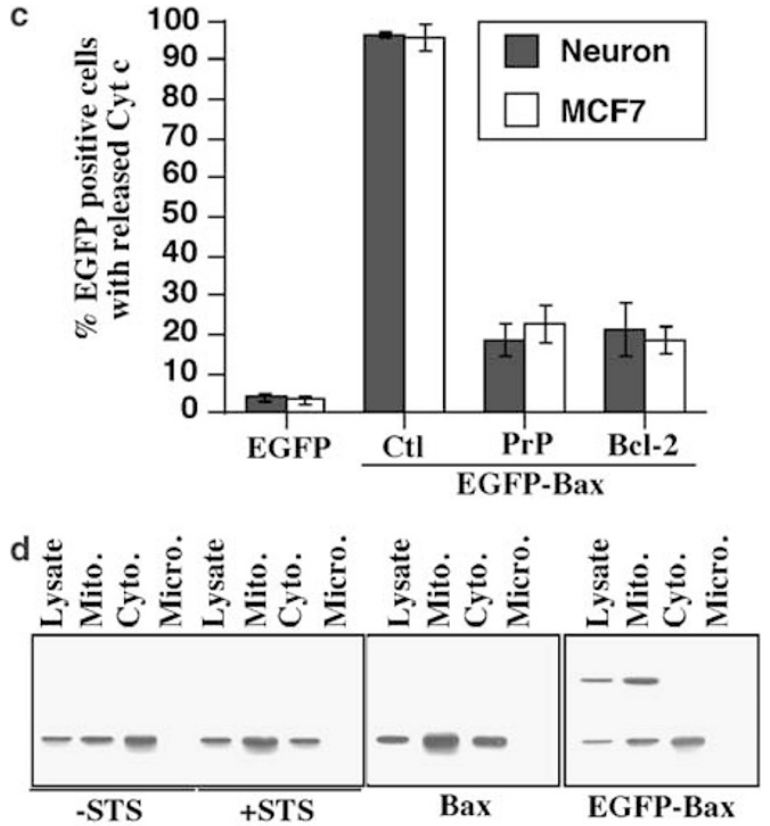

e

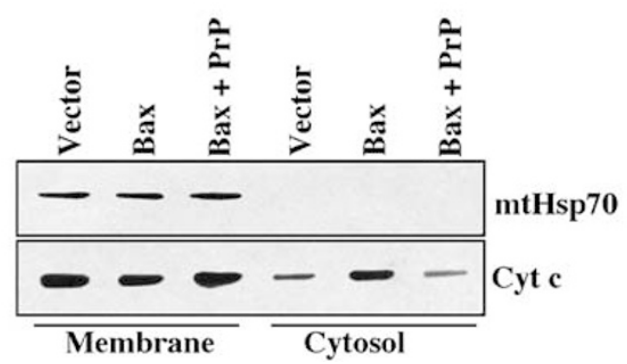

Figure 4 Continued

were treated with STS to induce endogenous Bax activation, whereas overexpression of Bax or EGFP-Bax was sufficient to activate cell death. A subcellular fractionation was performed to determine the location of Bax (Figure 4d). STS induces translocation of endogenous Bax from the cytosol to the mitochondria in mock-transfected cells. Bax overexpression also results in more mitochondrial Bax. Transfection of EGFP-Bax results in only mitochondrial EGFP-Bax without altering the location of endogenous Bax. These results show that expression of EGFP-Bax does not change the subcellular localization of endogenous Bax, but that it likely activates apoptosis by translocating to the mitochondria as do insultactivated endogenous Bax and overexpressed nontagged Bax.

To confirm that PrP can also inhibit non-EGFP-tagged Baxmediated cytochrome $c$ release, MCF-7 cells were transfected with empty vector, Bax or Bax and PrP before subcellular fractionation and immunoblotting to assess cytochrome $c$ release. Similar to the results observed in Figure $4 \mathrm{~b}$ and $\mathrm{c}$, PrP prevents the release of cytochrome $c$ from cells transfected with non-EGFP-tagged Bax (Figure 4e). These results show that $\operatorname{PrP}$ prevents cytochrome $c$ release from either EGFP-tagged or non-EGFP-tagged Bax-transfected cells. Together, the results indicate that PrP prevents

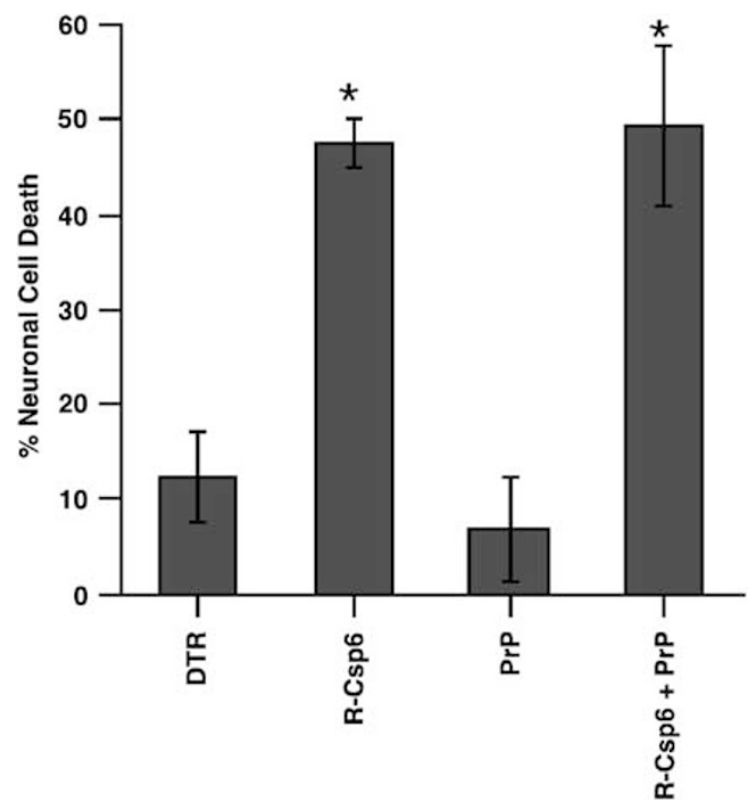

Figure 5 PrP does not prevent caspase-6-induced cell death in human neurons. TUNEL-positive cell death $24 \mathrm{~h}$ after neurons were microinjected with DTR, recombinant active caspase 6 (R-Csp6), pCep $4 \beta$-PrP or both pCep4 $\beta$-PrP and R-Csp6 (mean + S.D., $\left.n=4 ;{ }^{*} P<0.01\right)$

both Bax conformational change and Bax-mediated cytochrome $c$ release.

\section{PrP inhibits EGFP-Bax mitochondrial localization in MCF-7 cells but not in human neurons}

In human neurons, EGFP-Bax remains at the mitochondria in neurons cotransfected with PrP or Bcl-2 cDNAs (Figure 4a). Consequently, EGFP-Bax and cytochrome $c$ colocalize at the mitochondria. However, unlike our observations in neurons, EGFP-Bax accumulates in the cytosol in $60 \%$ of the MCF-7 cells cotransfected with $\mathrm{PrP}$ or $\mathrm{Bcl} 2 \mathrm{cDNAs}$, and localizes at the mitochondria in $40 \%$ of the cells (Figure $4 \mathrm{~b}$ ). One possible explanation for this finding is that EGFP-Bax is expressed or accumulates less in human neurons and that there are not enough copies of EGFP to be detected in the cytosol. However, it is also possible that in human neurons, Bax remains loosely attached to mitochondria as observed in subcellular fractionation studies (Figures $2 \mathrm{a}$ and $7 \mathrm{a}$ ).

\section{PrP does not inhibit cell death after the activation of caspases}

To determine if PrP can prevent caspase-mediated cell death in the absence of the upstream activation of Bax, neurons were coinjected with the active form of caspase- 6 previously shown to be the effector apoptotic caspase in human neurons. ${ }^{28,36} \mathrm{PrP}$ does not prevent caspase-6-mediated cell death (Figure 5). Therefore, in the mitochondrial apoptotic pathway, PrP antiapoptotic activity is limited to Bax conformational change. 

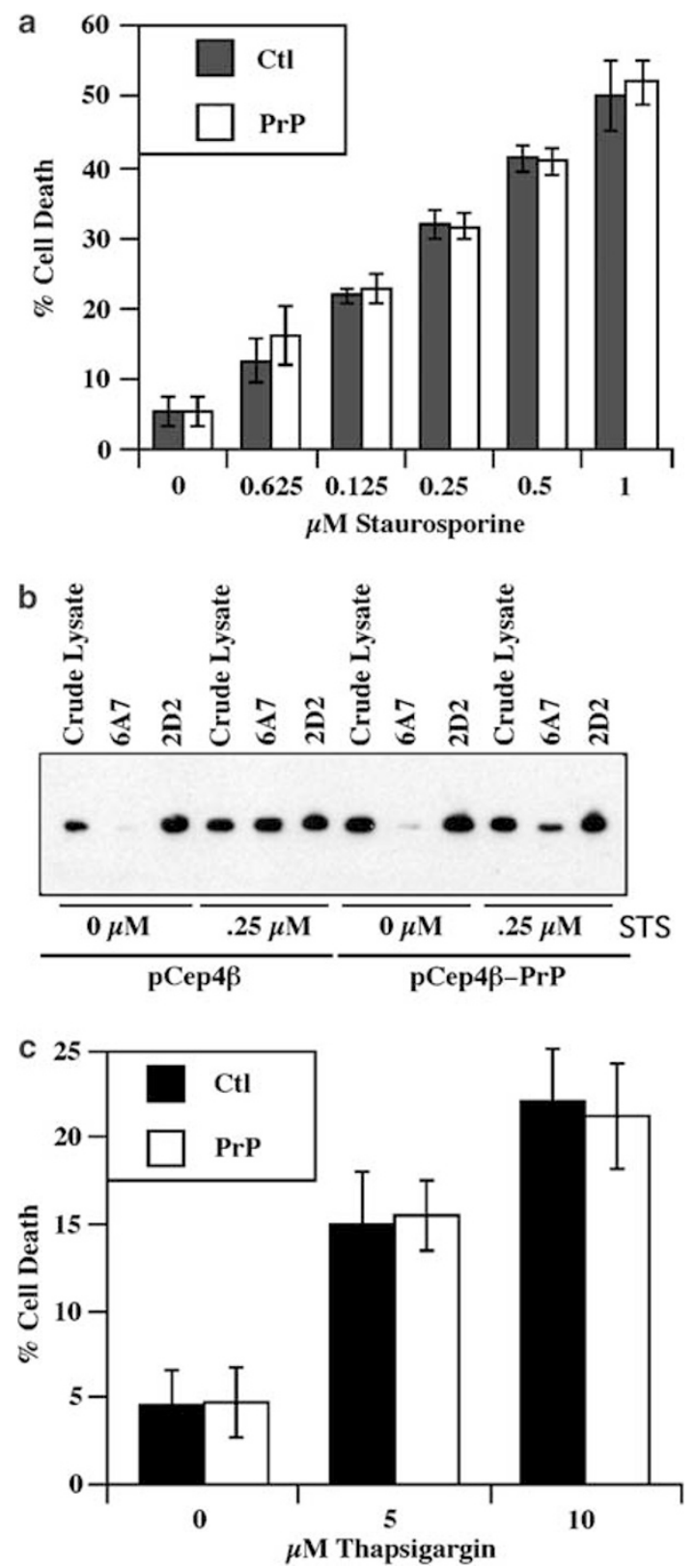

Figure 6 PrP does not prevent STS- and thapsigargin-induced cell death. (a) Hoescht-positive cell death of control mock-transfected MCF-7 cells (Ctl) and PrP overexpressing MCF-7 cells (PrP) treated with various concentrations of STS $24 \mathrm{~h}$ after the transfection. Data represent the mean and S.D. of three independent experiments. (b) Polyclonal N2O antibody Western blot analysis of Bax immunoprecipitated with 2D2 and 6A7 antibodies in CHAPS protein extracts from pCep $4 \beta$ - or pCep4 $\beta$-PrP-transfected MCF-7 cells treated with STS (STS) $24 \mathrm{~h}$ after transfection. Lysate represents $20 \%$ of total lysate before immunoprecipitation. (c) Hoescht-positive cell death of control mock-transfected MCF-7 cells (Ctl) and PrP overexpressing MCF-7 cells (PrP) treated with various concentrations of thapsigargin $24 \mathrm{~h}$ after the transfection. Data represent the mean and S.D. of three independent experiments

\section{PrP cannot prevent STS or thapsigargin-mediated apoptosis in MCF-7 cells}

PrP protects against Bax-mediated cell death induced by overexpression of Bax (Figure 3a) or EGFP-Bax (Figure 1a) and by serum deprivation. ${ }^{1}$ To assess if PrP may protect
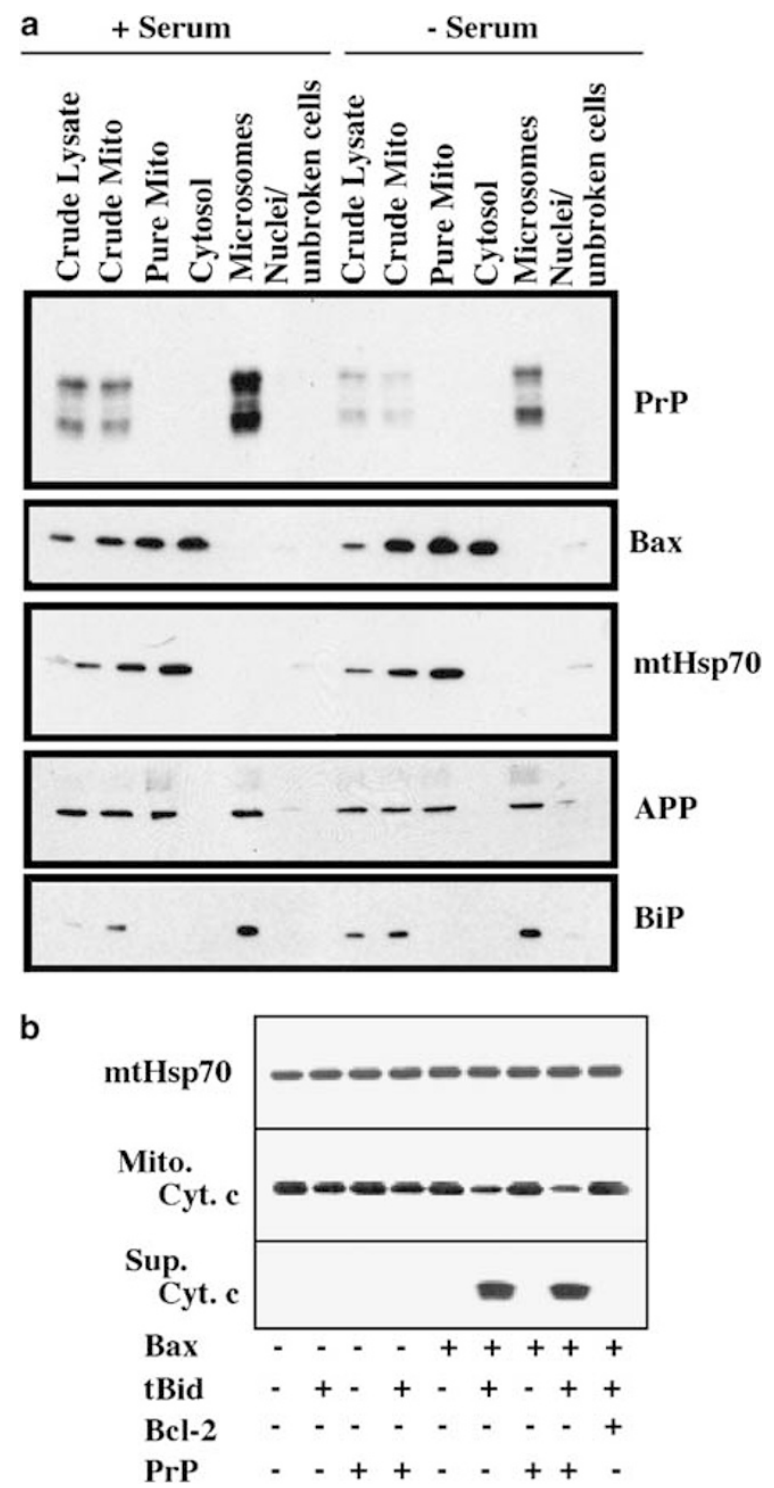

Figure 7 PrP cannot prevent Bax-mediated mitochondrial cytochrome $c$ release in a cell-free system. (a) Western blot analysis of PrP, Bax, mtHsp70, APP and Bip proteins in subcellular fractions from untreated (+ serum) and serum deprived (- serum) neurons. (b) Western blot analysis of cytochrome $c$ (Cyt. c) and mtHsp70 in mitochondria (mito.) and supernatant (Sup.) after incubation with recombinant tBid and Bax in the absence or presence of R-PrP or Bcl-2

against other proapoptotic insults, we investigated the ability of PrP to prevent kinase inhibitor STS and ER thapsigarginmediated apoptosis. PrP cannot prevent STS-induced cell death in MCF-7 cells (Figure 6a) despite being able to inhibit Bax conformational change (Figure 6b). Similarly, PrP does not prevent cell death induced by the ER stress, thapsigargin (Figure 6c). This could be explained by the fact that STS and thapsigargin activate $\mathrm{Bax}$ and $\mathrm{Bak}^{37}$ and $\mathrm{PrP}$ cannot prevent Bak-mediated cell death. However, we know that Bak kills MCF-7 cells very slowly (Figure 1e), so Bak cannot account for cell death in the STS- or thapsigargin-treated cells since they were treated for less than $24 \mathrm{~h}$. Therefore, these two drugs likely induce other pathways of cell death against which PrP is inefficient. 


\section{PrP does not inhibit Bax directly}

Previously, it has been shown that PrP accumulates in the cytosol of cells treated with proteasomal inhibitors. ${ }^{9,38-41}$ Furthermore, some neurons seem to only have cytosolic PrP. ${ }^{42}$ Since the accumulation of $\operatorname{PrP}$ in the cytosol provides an opportunity for PrP to interact directly with Bax as shown with other anti-Bax proteins, the subcellular localization of $\mathrm{PrP}$ was compared in normal and apoptotic neurons to assess if cytosolic PrP increases under apoptotic conditions and could colocalize with Bax. PrP is found mostly in the microsomal and in the crude mitochondrial fractions (Figure 7a). However, further purification of the mitochondria, characterized by an increase in mitochondrial Hsp70, showed that unlike Bax and APP, recently shown to have a mitochondrial localization signal, ${ }^{43} \operatorname{PrP}$ does not copurify with the mitochondria. In contrast, Bax is present mostly in mitochondria and the cytosol and is absent from the microsomes. Therefore, under apoptotic conditions, PrP does not accumulate in the cytosol and does not have this opportunity to interact with Bax.

Despite the lack of increased cytosolic PrP in apoptotic conditions, we must still consider that PrP could be found under some condition in the cytosol and thus could have access to Bax. Therefore, in some conditions, cytosolic PrP might directly interact with Bax to inhibit its conformational change. To assess if PrP can directly inhibit Bax activation in a cell-free system, the effect of R-PrP on recombinant tBid- and Bax-induced cytochrome $c$ release in isolated mitochondria was examined. Recombinant monomeric Bax and tBid alone do not induce the release of cytochrome $c$, as shown previously. ${ }^{44}$ Cytochrome $c$ release occurs from mitochondria treated with Bax and tBid (Figure7b and Roucou et al. ${ }^{44}$ ). As expected, Bcl-2 prevents cytochrome $c$ release. However, PrP is not able to prevent Bax-mediated cytochrome $c$ release in these conditions. Preincubation of Bax with PrP did not have any effect either. We conclude from these experiments that, unlike Bcl-2, but like BAR and BI-1, PrP probably cannot prevent Bax-mediated cell death by directly interacting with Bax.

\section{Discussion}

Previously, we have shown that PrP protects human neurons in primary cultures against Bax-mediated cell death detected by TUNEL-positive DNA fragmentation. ${ }^{8,9}$ However, the question of whether $\operatorname{PrP}$ inhibits cell death upstream or downstream of Bax remained to be answered. Bax-mediated apoptosis involves a complex series of events that initially includes the conformational change of Bax into a proapoptotic protein and Bax translocation from the cytosol to the mitochondria followed by an increase of mitochondrial permeability to release apoptogenic factors, cytochrome $c$, AIF and endonuclease $G$. In this paper, we investigated the level at which PrP inhibits Bax-mediated cell death. We found that PrP prevents the proapoptotic conformational change of Bax, the most distal step in Bax activation. Ectopic expression of PrP prevents the proapoptotic conformational change of Bax activation in human neurons and in MCF-7 cells triggered to undergo Bax-mediated apoptosis by overexpressing Bax or EGFP-Bax in these cells. Furthermore, Bax proapoptotic conformational change occurs more rapidly in serumdeprived cells that lack endogenous expression of PrP. Bcl2 has been shown to prevent Bax-mediated cell death without affecting cytochrome $c$ release in transfected HEK293T. ${ }^{33}$ Therefore, it was important to determine if PrP would inhibit cell death after cytochrome $c$ release. Our results indicate that this is not the case. We show that when PrP prevents Baxmediated cell death, cytochrome $c$ is always retained in the mitochondria. In addition, PrP cannot prevent caspase-6mediated cell death when the caspase is directly microinjected into the cytosol of human neurons. These results indicate that $\operatorname{PrP}$ is a potent Bax inhibitor that acts at the very first step of Bax activation and unexpectedly add PrP to the growing list of Bax inhibitors.

It is not clear at this time whether PrP acts directly or indirectly on Bax. Several inhibitors of Bax like humanin, Ku70, 14-3-3, crystallins and Hsp70 directly interact with Bax in the cytosol and prevent Bax translocation to the mitochondria. ${ }^{16-20}$ However, while a small amount of normal PrP is retrotranslocated from the ER to the cytosol ${ }^{9,38,39}$ and this PrP could directly interact with and prevent Bax conformational change, most of the PrP is present in the secretory pathway and attached at the cell surface through its glycophosphatidyl inositol anchor. We have shown here that the subcellular distribution of PrP does not change in serum-deprived induced apoptosis of human primary neurons. Furthermore, R-PrP does not prevent Bax and tBid-mediated cytochrome $c$ release from purified mitochondria in a cell-free system (Figure 7b). Therefore, unless $\operatorname{PrP}$ also needs to be in a specific conformation to inhibit Bax, it is unlikely that $\mathrm{PrP}$ acts directly by interacting with Bax.

Another possibility is that $\operatorname{PrP}$ acts through $\mathrm{Bcl}-2$ since, like $\mathrm{Bcl}-2,{ }^{32}$ PrP prevents Bax conformational change (Figure 2), Bax-mediated cell death ${ }^{8,9}$ and interacts with $\mathrm{Bcl}-2$. $^{4,46} \mathrm{PrP}^{-\prime-}$ cells are more sensitive to serum deprivation than $\mathrm{PrP}^{+/+}$ cells, a phenotype rescued by overexpression of either PrP or $\mathrm{Bcl}-2,{ }^{1}$ and both $\mathrm{PrP}$ and $\mathrm{Bcl}-2$ expression protect against oxidative stress. ${ }^{2,47} \mathrm{PrP}$ and $\mathrm{Bcl}-2$ do not prevent EGFP-Bax translocation to the mitochondria in human neurons and only partially prevent EGFP-Bax translocation in MCF-7 cells, but both $\mathrm{Bcl}-2$ and $\mathrm{PrP}$ prevent Bax-induced cytochrome $c$ release (Figure $4 \mathrm{a}$ and $\mathrm{b}$ ). ${ }^{48} \mathrm{Bcl}-2$ also does not have to be localized at the mitochondria to inhibit Bax as ER-targeted $\mathrm{Bcl}-2$ is also able to prevent Bax activation. ${ }^{49}$ However, unlike $\mathrm{Bcl}-2$, PrP cannot protect against Bak- or tBid-mediated cell death, ${ }^{50-53}$ prevent tBid- and Bax-mediated cytochrome $C$ release in a cell-free system (Figure $7 b$ ) and does not prevent Bax-mediated cell death in all cell types. ${ }^{54}$ Furthermore, PrP is localized mostly in the lumen of the ER rather than attached on the cytoplasmic surface of the ER via a transmembrane Cterminal domain like $\mathrm{Bcl}-2$. Therefore, PrP probably acts differently than $\mathrm{Bcl}-2$ in preventing Bax conformational change.

Another possibility is that PrP functions like BAR and $\mathrm{Bl}-1$. Both of these Bax inhibitors are localized in the ER as transmembrane proteins. ${ }^{14,15} \mathrm{BAR}$ and $\mathrm{BI}-1$ do not directly interact with Bax, but they do interact with Bcl-2 and Bcl-x. BAR also interacts with caspase- 8 and may function as a bridge between $\mathrm{Bcl}-2$ and caspase- $8 .^{14,55} \mathrm{Bl}-1$ inhibits thapsigargin-mediated cell death in mouse embryonic 
fibroblasts or the HT1080 human fibrosarcoma cell line by preventing calcium release and Bax activation. ${ }^{22}$ In contrast, PrP does not prevent thapsigargin-mediated cell death in MCF-7 cells (Figure 6c), indicating that PrP is not working through $\mathrm{BI}-1$. However, these two Bax inhibitors control Bax indirectly, a mechanism that is most consistent with PrP's localization in the secretory pathway.

A major difference between PrP and other Bax inhibitors is that PrP is quite specific to Bax-mediated cell death. PrP protection occurs only with Bax or EGFP-Bax overexpression, two insults that directly activate the Bax proapoptotic pathway. PrP cannot prevent Bak-, tBid-, STS- or thapsigarginmediated cell death. These last three insults are known to activate Bak in some cell lines, ${ }^{37,53,56}$ and this could explain why PrP cannot prevent cell death. However, Bak does not appear to play a major role in MCF-7 cell death until after $24 \mathrm{~h}$ of the insult, indicating that STS and thapsigargin likely activate other cell death pathways that PrP cannot prevent.

To find the underlying molecular mechanism by which PrP prevents Bax conformational change will not be easy. Although it is clearly established that Bax conformational change involves a structural rearrangement in the $\mathrm{N}$ - and $\mathrm{C}$ terminal domains of the protein, little is known about how Bax is activated. Some have reported that a decrease in cellular cytosolic $\mathrm{pH}$, interaction of Bax with membranes and oligomerization result in Bax proapoptotic conformational change. ${ }^{57-61}$ Which of these potential mechanisms is targeted by the well-known $\mathrm{Bax}$ inhibitor, $\mathrm{Bcl}-2$, have been under intense investigations for years, but have not yet been elucidated.

In summary, we have shown that PrP prevents Baxmediated cell death by inhibiting Bax proapoptotic conformational change, but not Bax translocation, in human neurons and MCF-7 cells. This is the first example, other than Bcl-2, in which a Bax inhibitor does not prevent Bax translocation to the mitochondria, but clearly inhibits Bax proapoptotic conformational change and cell death. These results unexpectedly add PrP to the growing list of Bax inhibitors and imply that care need to be taken if ablation of PrP as a method to prevent infectious prion diseases is to be considered as a therapy. It is possible that this significant neuroprotective role of PrP may be very important to protect the brain against pathological conditions.

\section{Materials and Methods}

\section{Antibodies}

Monoclonal 2D2, 6A7 and polyclonal N20 anti-Bax antibodies were purchased from Trevigen (Gaithersburg, MD, USA), BD Pharmingen (Mississauga, ON, Canada) and Santa Cruz Biotechnology (Santa Cruz, CA, USA), respectively. Monoclonal anti-mitochondrial Hsp70 (mtHsp70; clone JG1), anti- $\beta$-actin (clone $A C$-15) and monoclonal antibodies recognizing either the native (clone $6 \mathrm{H} 2 . \mathrm{B} 4$ for immunostaining) or the denatured (clone $7 \mathrm{H} 8.2 \mathrm{C} 12$ for Western blots) forms of cytochrome $c$ were purchased from Affinity BioReagents (Golden, CO, USA), Sigma (Oakville, ON, Canada), Chemicon (Temecula, CA, USA) and BD Pharmingen (Mississauga, ON, Canada), respectively. The APP antibody 22C11 was purchased from Roche Diagnostics (Montreal, QC, Canada). Fluorescein5-isothiocyanate (FITC)-conjugated sheep affinity-purified antibodies to mouse IgG (Bax immunostaining) and tetramethylrhodamine-5 (and-6)isothiocyanate-conjugated goat lg $\mathrm{G}$ fraction to mouse $\lg \mathrm{G}$ (for cytochrome $c$ immunostaining) were purchased from Rockland Immunochemicals (Bridgeport, NJ, USA).

\section{Clones}

Cloning of EGFP, EGFP-Bax, PrP and Bcl-2 in pCep4 $\beta$ (Invitrogen, Burlington, ON, Canada) was described previously. ${ }^{8,9}$ Human Bak was amplified by PCR amplification from the pcDNA3.1-Bak construct (a generous gift from Dr. Shigemi Matsuyama, Blood Research Institute, Department of Biochemistry, Medical College of Wisconsin), using upstream primer $5^{\prime}$-CTCAAGCTTAAAATGGC TTCGGGGCAAGGC-3' and downstream primer 5'-CCGTCTCGAGTCATGATTTGAAGAAT CTTCG- $3^{\prime}$. The PCR product was cloned in the Xhol and Hindll sites of the mammalian expression vector pCep4 $\beta$-EGFP. tBid-DsRed2 was amplified from pDsRed2-Bid (Clontech; Mississauga, ON, Canada), using upstream primer 5'-GGGGTACCATGGATGGCAACCGCAGCAGC CACTCC- $3^{\prime}$ and downstream primer $5^{\prime}$-CCGCTCGAGCTACAGGAA CAGGTGGTGGCGGC-3'. The PCR product was cloned in the Kpnl and $X$ hol sites of $p C e p 4 \beta$. For the pBud construct, EGFP was amplified from the pCep $4 \beta$-EGFP construct using upstream primer 5 -TTTGGTAC CATGGTGAGCAAGGGCGAG-3' and downstream primer $5^{\prime}$-GGGA GATCTACTTGTACAGCTCGTCCAT-3'. The PCR product was cloned in the Kpnl and Bgll sites located downstream of the EF- $1 \alpha$ promoter, generating $\mathrm{pBudCE} 4.1$-EGFP. PrP was amplified from the $\mathrm{pCep} 4 \beta$-PrP construct using upstream primer $5^{\prime}$-ATATGTCGACATGGCGAACC TTGGCTGCTGGAT-3' and downstream primer $5^{\prime}$-CGCGTCTAGAT CATCCCACTATCAGGAAGAT-3'. The PCR product was cloned in the Sall and $X$ bal sites of pBudCE4.1-EGFP located downstream of the CMV promoter, generating pBudCE4.1-EGFP-PrP.

\section{Cell culture and treatments}

Human primary neurons were cultured as described. ${ }^{27,62}$ Hippocampal HW3-5 and HpL3-4 cell lines established from $\mathrm{PrP}^{+1+}$ and $\mathrm{PrP}^{-1-}$ mice, respectively, were a kind gift from Dr. T Onodera (University of Tokyo, Japan) and were serum-deprived as described previously. ${ }^{1}$ MCF-7 cells were obtained from ATCC. HW3-5, HpL3-4 and MCF-7 cells were maintained in DMEM containing $10 \%$ fetal calf serum. Serum deprivation was carried out for $24 \mathrm{~h}$ on human neurons and $0-72 \mathrm{~h}$ on HW3-5 and HpL3-4 cell lines. Apoptosis was induced with 0.25 or $0.5 \mu \mathrm{M}$ STS for $10 \mathrm{~h}$ in human neurons and $0.25 \mu \mathrm{M}$ for $10 \mathrm{~h}$ in MCF-7 cells. MCF-7 cells were treated with 5 or $10 \mu \mathrm{M}$ thapsigargin for $24 \mathrm{~h}$.

\section{Transfections}

Human neurons were plated at a cell density of $3 \times 10^{6} \mathrm{cell} / \mathrm{s} / \mathrm{ml}$ onto polyD-lysine- $(20 \mu \mathrm{g} / \mathrm{ml}$; Sigma, St. Louis, MI, USA) and laminin- $(10 \mu \mathrm{g} / \mathrm{ml}$; Sigma) coated glass coverslips in 24-well plates. Neurons were transfected using $3.3 \mu \mathrm{l}$ ExGen 500 and $1.6 \mu \mathrm{g}$ DNA per 150000 cells according to the manufacturer's protocol (MBI; Burlington, ON, Canada). Alternatively, neurons were transfected with $1 \mu \mathrm{g} \mathrm{DNA} /$ shot using the Helios Gene Gun System from BioRad (Mississauga, ON, Canada) at a shooting pressure of $220 \mathrm{psi}$ according to the manufacturer's protocol. Briefly, transfection cartridges were prepared with $0.033 \mathrm{mg}$ DNA for a single construct and three times more of a second construct $(0.099 \mathrm{mg})$, $4.2 \mathrm{mg}$ gold microcarrier beads in $0.1 \mathrm{ml}$ calcium chloride $1 \mathrm{M}$ and $0.1 \mathrm{ml}$ $0.05 \mathrm{M}$ spermidine. The beads were centrifuged and washed three times with 100\% ethanol and resuspended in $2 \mathrm{ml} 100 \%$ ethanol before coating 
the cartridges. The cartridges had a microcarrier loading quantity of $0.125 \mathrm{mg}$ gold $/ \mathrm{shot}$ and a DNA loading ratio of $8 \mu \mathrm{g}$ DNA $/ \mathrm{mg}$ gold.

MCF-7 cells of $90 \%$ confluence were transfected with $4 \mu \mathrm{g}$ DNA using Lipofectamine 2000 (Invitrogen, Burlington, ON, Canada). MCF-7 cells at $50 \%$ confluence were transfected with the Helios Gene Gun System as described above for human neurons. When transfecting two constructs, MCF7 cells were transfected with a $1: 3$ ratio of pCep4 $\beta$-EGFPBax: $\mathrm{pCep} 4 \beta$, or pCep $4 \beta$-EGFP-Bax: $\mathrm{pCep} 4 \beta$-PrP, or pCep4 $\beta$-EGFPBax: $\mathrm{pCep} 4 \beta$-Bcl-2. When transfecting three constructs, MCF-7 cells were transfected with a $1: 6$ ratio of $\mathrm{pCep} 4 \beta$-EGFP : $\mathrm{pCep} 4 \beta$, or a $1: 2: 4$ ratio of $\mathrm{pCep} 4 \beta$-EGFP:pCep $4 \beta$-Bax:pCep $4 \beta$-, pCep $4 \beta$-EGFP: $\mathrm{pCep} 4 \beta$ Bax : pCep $4 \beta$-PrP or pCep $4 \beta$-EGFP : pCep4 $\beta$-Bax : pCep $4 \beta$-Bcl-2.

\section{Microinjection}

Microinjections were performed as described. ${ }^{8,63,28} \mathrm{R}-\mathrm{Csp} 6$ was prepared in caspase- 6 active buffer containing $20 \mathrm{mM}$ piperazine- $N, N^{\prime}$-bis-(2ethanesulfonic acid) (PIPES), $100 \mathrm{mM} \mathrm{NaCl}, 10 \mathrm{mM}$ dithiothreitol (DTT), $1 \mathrm{mM}$ EDTA, 0.1\% 3-[(3-cholamidopropyl)-dimethylammonio]-2-hydroxy1-propanesulfonic acid (CHAPS) and 10\% sucrose, pH 7.2. In all, $25 \mathrm{pg}$ RCsp6 with or without $25 \mathrm{pg}$ of $\mathrm{pCep} 4 \beta$-PrP were injected per cell in a volume of $1 \mathrm{nl}$. In total, $2.5 \mathrm{pg}$ DTR (Cedarlane, Hornby, ON, Canada) were coinjected as a fluorescent marker to recognize injected neurons. For the Bak microinjections, neurons were injected with 25 pg pCep4 $\beta$-EGFP. Bak with or without $25 \mathrm{pg}$ of $\mathrm{pCep} 4 \beta$-PrP.

\section{Cell death measurements}

Microinjected neuronal cell death was carried out as described previously. ${ }^{28}$ Briefly, DTR (Cedarlane, Hornby, ON, Canada) was coinjected as a fluorescent marker to detect injected neurons. Cell death was assessed $48 \mathrm{~h}$ postmicroinjection by TUNEL according to the manufacturer's protocol (In Situ Cell Death Detection Kit (A, P), Roche Applied Science, Laval, QC, Canada). Transfected human neuronal cell death was also determined by TUNEL using the TMR-red for cells transfected with EGFP-expressing constructs and fluorescein-labeled nucleotides for the detection of cells transfected with DsRed2-expressing constructs. The percentage of neuronal apoptosis was determined by the ratio of the number of DTR and TUNEL double-positive neurons over the total number of DTR-positive neurons. Cell death in MCF7 cells was measured by counting EGFP-positive cells displaying condensed chromatin stained with $1 \mu \mathrm{g} / \mathrm{ml}$ Hoescht 33342 versus total number of EGFP-positive cells.

\section{Immunoprecipitation}

Proteins were extracted in NP-40 or CHAPS lysis buffer ( $150 \mathrm{mM}$ sodium chloride, $50 \mathrm{mM}$ Tris- $\mathrm{HCl}$ (pH 8.0), $1 \% \mathrm{NP}-40$ or $1 \%$ CHAPS), and Bax was immunoprecipitated with monoclonal 2D2 or $6 \mathrm{~A} 7$ antibodies $(1 / 100$ dilution). ${ }^{64}$ Bax was detected by Western blotting with polyclonal N2O antibody (1/3000 dilution).

\section{Subcellular fractionation, Bax oligomerization and cytochrome $c$ release}

Cells were harvested in PBS and homogenized with a Dounce homogenizer in buffer $\mathrm{A}$ ( $8 \%$ sucrose, $20 \mathrm{mM}$ Tricine, $1 \mathrm{mM}$ EDTA, $\mathrm{pH}$ 7.8) supplemented with complete protease inhibitor mixture (Roche Applied Science, Laval, QC, Canada). Subcellular fractionation was performed as described. ${ }^{31}$ Mitochondrial proteins were fractionated on a Superdex 200 column (16/60) as described previously. ${ }^{31,44}$ The presence of cytochrome $\mathrm{c}, \mathrm{mtHsp} 70$ and $\beta$-actin in mitochondria-containing heavy membrane fraction and cytosol was analyzed by western Blotting with monoclonal antibodies (1/1000 dilution).

\section{Immunofluorescence}

Cells were fixed for 20 min with $4 \%$ paraformaldehyde and $4 \%$ sucrose $24 \mathrm{~h}$ after transfection (cytochrome $c$ release in neurons and MCF-7 cells) or microinjection (Bax conformational change in neurons). Cells were permeabilized with either $0.2 \%$ CHAPS in PBS for 2 min (Bax immunostaining with $2 \mathrm{D} 2$ or $6 \mathrm{~A} 7$ ) or with $0.2 \%$ Triton $\mathrm{X}-100$ in PBS for 10 min (cytochrome $c$ immunostaining with monoclonal $6 \mathrm{H} 2 . \mathrm{B} 4$ ) at room temperature. After washing, the cells were incubated overnight with monoclonal antibodies (1: 100 dilution in PBS $+10 \%$ normal goat serum), washed twice in PBS and detected with secondary anti-mouse antibodies (1/100 dilution). Fluorescein-5-isothiocyanate- and tetramethylrhodamine5-isothiocyanate-conjugated secondary antibodies were used to detect Bax and cytochrome $c$, respectively. In the last wash, $1 \mu \mathrm{g} / \mathrm{ml}$ of Hoescht 33342 was added to stain cellular nuclei. Coverslips were mounted on with the SlowFade Light Antifade Kit (Molecular Probes, Eugene, OR, USA) and observed by conventional epifluorescence microscopy using a Nikon eclipse TE2000-U microscope (Mississauga, ON, Canada). Images were acquired with an Orca-ER CCD camera (Improvision, Guelph, ON, Canada), Openlab (Improvision, Guelph, ON, Canada) and Adobe Photoshop 6.0 (Ottawa, ON, Canada) softwares.

\section{Cell-free mitochondrial release of cytochrome $c$}

Mitochondria were isolated from mouse liver and purified in a sucrose gradient as described previously. ${ }^{65}$ Mitochondria $(0.1 \mathrm{mg})$ were added to $0.1 \mathrm{ml}$ of release buffer $(210 \mathrm{mM}$ mannitol, $70 \mathrm{mM}$ sucrose, $10 \mathrm{mM}$ Hepes: $\mathrm{NaOH}$, pH 7.4, 0.5 mM EGTA, $5 \mathrm{mM}$ succinate, $4 \mathrm{mM} \mathrm{MgCl}_{2}$ and $5 \mathrm{mM} \mathrm{Na}_{2} \mathrm{HPO}_{4}$ ). Recombinant monomeric full-length Bax (R-Bax, $100 \mathrm{nM}$ ) was added in the absence or presence of $5 \mathrm{nM}$ recombinant tBid (R-tBid), $600 \mathrm{nM}$ recombinant Bcl-2 (R-Bcl-2) or $600 \mathrm{nM} \mathrm{R-PrP,} \mathrm{and}$ the mitochondria were incubated for $30 \mathrm{~min}$ at $30^{\circ} \mathrm{C}$. Mitochondria were centrifuged for $10 \mathrm{~min}$ at $10000 \times \mathrm{g}$. The presence of cytochrome $c$ was analyzed in the pellet by Western blotting using monoclonal $7 \mathrm{H} 8.2 \mathrm{C} 12$ antibodies. R-Bax and R-tBid were obtained from Professor Jean-Claude Martinou (University of Geneva, Geneva, Switzerland). R-PrP was a gift from Dr. Witold Surewicz (Case Western University, Cleveland, OH, USA). R-Bcl-2 was purchased from Cedarlane Lab. Ltd (Hornby, ON, Canada).

\section{Statistical evaluation}

Statistical differences were analyzed with analysis of variance followed by post hoc Scheffé's test using StatView (SAS Institute Inc., Cary, NC, USA). A $P<0.05$ was taken as a significant difference.

\section{Acknowledgements}

We thank Dr. Onodera (University of Tokyo, Japan) for providing immortalized mouse hippocampal cell lines HW3-5 and HpL3-4, Dr. JeanClaude Martinou (University of Geneva, Switzerland) and Dr. Witold Surewicz (Case Western Reserve University, OH, USA) for their kind gift of recombinant Bax, tBid and PrP proteins, respectively, Dr. Shigemi Matsuyama (Medical College of Wisconsin, WI, USA) for the Bak 
construct, and Jennifer Hammond for technical assistance. This work was supported by the National Institutes of Health (R01 NS40431), Canadian Institute of Health Research, Fond de Recherches en Santé du Québec and Valorisation Recherche Québec.

\section{References}

1. Kuwahara C, Takeuchi AM, Nishimura T, Haraguchi K, Kubosaki A, Matsumoto Y, Saeki K, Yokoyama T, Itohara S and Onodera T (1999) Prions prevent neuronal cell-line death. Nature 400: 225-226

2. Brown DR, Nicholas RS and Canevari L (2002) Lack of prion protein expression results in a neuronal phenotype sensitive to stress. J. Neurosci. Res. 67: 211-224

3. Zanata SM, Lopes MH, Mercadante AF, Haij GN, Chiarini LB, Nomizo R, Freitas AR, Cabral AL, Lee KS, Juliano MA, de Oliveira E, Jachieri SG, Burlingame A, Huang L, Linden R, Brentani RR and Martins VR (2002) Stressinducible protein 1 is a cell surface ligand for cellular prion that triggers neuroprotection. EMBO J. 21: 3307-3316

4. Chiarini LB, Freitas AR, Zanata SM, Brentani RR, Martins VR and Linden R (2002) Cellular prion protein transduces neuroprotective signals. EMBO J. 21: $3317-3326$

5. Shmerling D, Hegyi I, Fischer M, Blattler T, Brandner S, Gotz J, Rulicke T, Flechsig E, Cozzio A, von Mering C, Hangartner C, Aguzzi A and Weissmann C (1998) Expression of amino-terminally truncated PrP in the mouse leading to ataxia and specific cerebellar lesions. Cell 93: 203-214

6. Nishida N, Tremblay P, Sugimoto T, Shigematsu K, Shirabe S, Petromilli C, Erpel SP, Nakaoke R, Atarashi R, Houtani T, Torchia M, Sakaguchi S, DeArmond SJ and Prusiner SB andKatamine S (1999) A mouse prion protein transgene rescues mice deficient for the prion protein gene from Purkinje cell degeneration and demyelination. Lab. Invest. 79: 689-697

7. Diarra-Mehrpour M, Arrabal S, Jalil A, Pinson X, Gaudin C, Pietu G, Pitaval A, Ripoche H, Eloit M, Dormont D and Chouaib S (2004) Prion protein prevents human breast carcinoma cell line from tumor necrosis factor alpha-induced cell death. Cancer Res. 64: 719-727

8. Bounhar Y, Zhang Y, Goodyer CG and LeBlanc A (2001) Prion protein protects human neurons against Bax-mediated apoptosis. J. Biol. Chem. 276: 3914539149

9. Roucou X, Guo Q, Zhang Y, Goodyer CG and LeBlanc AC (2003) Cytosolic prion protein is not toxic and protects against Bax-mediated cell death in human primary neurons. J. Biol. Chem. 278: 40877-40881

10. White FA, Keller-Peck CR, Knudson CM, Korsmeyer SJ and Snider WD (1998) Widespread elimination of naturally occurring neuronal death in Bax-deficient mice. J. Neurosci. 18: 1428-1439

11. Deckwerth TL, Elliott JL, Knudson CM, Johnson Jr EM, Snider WD and Korsmeyer SJ (1996) BAX is required for neuronal death after trophic factor deprivation and during development. Neuron 17: 401-411

12. Desagher S and Martinou JC (2000) Mitochondria as the central control point of apoptosis. Trends Cell Biol. 10: 369-377

13. Martinou JC and Green DR (2001) Breaking the mitochondrial barrier. Nat. Rev. Mol. Cell. Biol. 2: 63-67

14. Zhang H, Xu Q, Krajewski S, Krajewska M, Xie Z, Fuess S, Kitada S, Pawlowski K, Godzik A and Reed JC (2000) BAR: an apoptosis regulator at the intersection of caspases and Bcl-2 family proteins. Proc. Natl. Acad. Sci. USA 97: 2597-2602

15. Xu Q and Reed JC (1998) Bax inhibitor-1, a mammalian apoptosis suppressor identified by functional screening in yeast. Mol. Cell 1: 337-346

16. Tsuruta F, Sunayama J, Mori Y, Hattori S, Shimizu S, Tsujimoto Y, Yoshioka K, Masuyama N and Gotoh $Y$ (2004) JNK promotes Bax translocation to mitochondria through phosphorylation of 14-3-3 proteins. EMBO J. 23: 18891899

17. Sawada M, Sun W, Hayes P, Leskov K, Boothman DA and Matsuyama S (2003) Ku70 suppresses the apoptotic translocation of Bax to mitochondria. Nat. Cell Biol. 5: 320-329

18. Guo B, Zhai D, Cabezas E, Welsh K, Nouraini S, Satterthwait AC and Reed JC (2003) Humanin peptide suppresses apoptosis by interfering with Bax activation. Nature 423: 456-461
19. Gotoh T, Terada K, Oyadomari S and Mori M (2004) Hsp70-DnaJ chaperone pair prevents nitric oxide- and CHOP-induced apoptosis by inhibiting translocation of Bax to mitochondria. Cell Death Differ. 11: 390-402

20. Mao YW, Liu JP, Xiang H and Li DW (2004) Human alphaA- and alphaBcrystallins bind to $\mathrm{Bax}$ and $\mathrm{Bcl}-\mathrm{X}(\mathrm{S})$ to sequester their translocation during staurosporine-induced apoptosis. Cell. Death Differ. 11: 512-526

21. Desagher S, Osen-Sand A, Nichols A, Eskes R, Montessuit S, Lauper S, Maundrell K, Antonsson B and Martinou JC (1999) Bid-induced conformational change of Bax is responsible for mitochondrial cytochrome $c$ release during apoptosis. J. Cell Biol. 144: 891-901

22. Chae HJ, Kim HR, Xu C, Bailly-Maitre B, Krajewska M, Krajewski S, Banares S, Cui J, Digicaylioglu M, Ke N, Kitada S, Monosov E, Thomas M, Kress CL, Babendure JR, Tsien RY, Lipton SA and Reed JC (2004) BI-1 regulates an apoptosis pathway linked to endoplasmic reticulum stress. Mol. Cell 15: 355-366

23. Kiefer MC, Brauer MJ, Powers VC, Wu JJ, Umansky SR, Tomei LD and Barr PJ (1995) Modulation of apoptosis by the widely distributed Bcl-2 homologue Bak. Nature 374: 736-739

24. Chittenden T, Flemington C, Houghton AB, Ebb RG, Gallo GJ, Elangovan B, Chinnadurai $G$ and Lutz RJ (1995) A conserved domain in Bak, distinct from $\mathrm{BH} 1$ and $\mathrm{BH} 2$, mediates cell death and protein binding functions. EMBO J. 14: 5589-5596

25. Wang K, Yin XM, Chao DT, Milliman CL and Korsmeyer SJ (1996) BID: a nove BH3 domain-only death agonist. Genes Dev. 10: 2859-2869

26. Korsmeyer SJ, Wei MC, Saito M, Weiler S, Oh KJ and Schlesinger PH (2000) Pro-apoptotic cascade activates BID, which oligomerizes BAK or BAX into pores that result in the release of cytochrome $c$. Cell Death Differ. 7: 1166-1173

27. LeBlanc A (1995) Increased production of $4 \mathrm{kDa}$ amyloid beta peptide in serum deprived human primary neuron cultures: possible involvement of apoptosis. J. Neurosci. 15: 7837-7846

28. Zhang Y, Goodyer $C$ and LeBlanc A (2000) Selective and protracted apoptosis in human primary neurons microinjected with active caspase- $-3,-6,-7$, and -8 . J. Neurosci. 20: 8384-8389

29. Zhang $Y$, Hong $Y$, Bounhar $Y$, Blacker M, Roucou X, Tounekti O, Vereker E, Bowers WJ, Federoff HJ, Goodyer CG and LeBlanc A (2003) p75 neurotrophin receptor protects primary cultures of human neurons against extracellular amyloid beta peptide cytotoxicity. J. Neurosci. 23: 7385-7394

30. Hsu YT and Youle RJ (1997) Nonionic detergents induce dimerization among members of the Bcl-2 family. J. Biol. Chem. 272: 13829-13834

31. Antonsson B, Montessuit S, Sanchez B and Martinou JC (2001) Bax is present as a high molecular weight oligomer/complex in the mitochondrial membrane of apoptotic cells. J. Biol. Chem. 276: 11615-11623

32. Murphy KM, Streips UN and Lock RB (2000) Bcl-2 inhibits a Fas-induced conformational change in the Bax $\mathrm{N}$ terminus and Bax mitochondrial translocation. J. Biol. Chem. 275: 17225-17228

33. Rosse T, Olivier R, Monney L, Rager M, Conus S, Fellay I, Jansen B and Borner C (1998) Bcl-2 prolongs cell survival after Bax-induced release of cytochrome c. Nature 391: 496-499

34. Lipscomb EA, Sarmiere PD and Freeman RS (2001) SM-20 is a novel mitochondrial protein that causes caspase-dependent cell death in nerve growth factor-dependent neurons. J. Biol. Chem. 276: 5085-5092

35. Deshmukh M and Johnson Jr EM (1998) Evidence of a novel event during neuronal death: development of competence-to-die in response to cytoplasmic cytochrome c. Neuron 21: 695-705

36. LeBlanc A, Liu H, Goodyer C, Bergeron C and Hammond J (1999) Caspase-6 role in apoptosis of human neurons, amyloidogenesis, and Alzheimer's disease. J. Biol. Chem. 274: 23426-23436

37. Wei MC, Zong WX, Cheng EH, Lindsten T, Panoutsakopoulou V, Ross AJ, Roth KA, MacGregor GR, Thompson CB and Korsmeyer SJ (2001) Proapoptotic $\mathrm{BAX}$ and $\mathrm{BAK}$ : a requisite gateway to mitochondrial dysfunction and death. Science 292: 727-730

38. Yedidia Y, Horonchik L, Tzaban S, Yanai A and Taraboulos A (2001) Proteasomes and ubiquitin are involved in the turnover of the wild-type prion protein. EMBO J. 20: 5383-5391

39. Ma J and Lindquist S (2001) Wild-type PrP and a mutant associated with prion disease are subject to retrograde transport and proteasome degradation. Proc. Natl. Acad. Sci. USA 98: 14955-14960

40. Zanusso G, Petersen RB, Jin T, Jing Y, Kanoush R, Ferrari S, Gambetti P and Singh N (1999) Proteasomal degradation and N-terminal protease resistance of the codon 145 mutant prion protein. J. Biol. Chem. 274: 23396-23404 
41. Rane NS, Yonkovich JL and Hegde RS (2004) Protection from cytosolic prion protein toxicity by modulation of protein translocation. EMBO J. 23: 4550-4559

42. Mironov Jr A, Latawiec D, Wille $H$, Bouzamondo-Bernstein $E$, Legname $G$ Williamson RA, Burton D, DeArmond SJ, Prusiner SB and Peters PJ (2003) Cytosolic prion protein in neurons. J. Neurosci. 23: 7183-7193

43. Anandatheerthavarada HK, Biswas G, Robin MA and Avadhani NG (2003) Mitochondrial targeting and a novel transmembrane arrest of Alzheimer's amyloid precursor protein impairs mitochondrial function in neuronal cells. J. Cell Biol. 161: 41-54

44. Roucou X, Montessuit S, Antonsson B and Martinou JC (2002) Bax oligomerization in mitochondrial membranes requires tBid (caspase-8cleaved Bid) and a mitochondrial protein. Biochem. J. 368 (Part 3): 915-921

45. Kurschner C and Morgan $\mathrm{JI}$ (1996) Analysis of interaction sites in homo- and heteromeric complexes containing Bcl-2 family members and the cellular prion protein. Brain Res. Mol. Brain Res. 37: 249-258

46. Kurschner $\mathrm{C}$ and Morgan JI (1995) The cellular prion protein (PrP) selectively binds to Bcl-2 in the yeast two-hybrid system. Brain Res. Mol. Brain Res. 30: $165-168$

47. Hockenbery DM, Oltvai ZN, Yin XM, Milliman CL and Korsmeyer SJ (1993) Bcl2 functions in an antioxidant pathway to prevent apoptosis. Cell 75: 241-251

48. Putcha GV, Deshmukh M and Johnson Jr EM (1999) BAX translocation is a critical event in neuronal apoptosis: regulation by neuroprotectants, BCL-2, and caspases. J. Neurosci. 19: 7476-7485

49. Thomenius MJ, Wang NS, Reineks EZ, Wang Z and Distelhorst CW (2003) Bcl2 on the endoplasmic reticulum regulates Bax activity by binding to $\mathrm{BH}$-only proteins. J. Biol. Chem. 278: 6243-6250

50. Cheng EH, Wei MC, Weiler S, Flavell RA, Mak TW, Lindsten T and Korsmeyer SJ (2001) BCL-2, BCL-X(L) sequester BH3 domain-only molecules preventing BAX- and BAK-mediated mitochondrial apoptosis. Mol. Cell 8: 705-711

51. Lamothe B and Aggarwal BB (2002) Ectopic expression of Bcl-2 and Bcl-xL inhibits apoptosis induced by TNF-related apoptosis-inducing ligand (TRAIL) through suppression of caspases-8, 7 , and 3 and BID cleavage in human acute myelogenous leukemia cell line HL-60. J. Interferon Cytokine Res. 22: 269-279

52. Werner AB, de Vries E, Tait SW, Bontjer I and Borst J (2002) Bcl-2 family member $\mathrm{Bfl}-1 / \mathrm{A} 1$ sequesters truncated bid to inhibit is collaboration with proapoptotic Bak or Bax. J. Biol. Chem. 277: 22781-22788

53. Ruffolo SC and Shore GC (2003) BCL-2 selectively interacts with the BIDinduced open conformer of BAK, inhibiting BAK auto-oligomerization. J. Biol. Chem. 278: 25039-25045
54. Roucou X, Gains M and LeBlanc AC (2004) Neuroprotective functions of prion protein. J. Neurosci Res. 75: 153-161

55. Stegh AH, Barnhart BC, Volkland J, Algeciras-Schimnich A, Ke N, Reed JC and Peter ME (2002) Inactivation of caspase-8 on mitochondria of Bcl-xLexpressing MCF7-Fas cells: role for the bifunctional apoptosis regulator protein. J. Biol. Chem. 277: 4351-4360

56. Yi X, Yin XM and Dong Z (2003) Inhibition of Bid-induced apoptosis by Bcl-2. tBid insertion, Bax translocation, and Bax/Bak oligomerization suppressed. J. Biol. Chem. 278: 16992-16999

57. Yethon JA, Epand RF, Leber B, Epand RM and Andrews DW (2003) Interaction with a membrane surface triggers a reversible conformational change in Bax normally associated with induction of apoptosis. J. Biol. Chem. 278: 4893548941

58. Belaud-Rotureau MA, Leducq N, Macouillard Poulletier de Gannes F, Diolez P, Lacoste L, Lacombe F, Bernard P and Belloc F (2000) Early transitory rise in intracellular $\mathrm{pH}$ leads to Bax conformation change during ceramide-induced apoptosis. Apoptosis. 5: 551-560

59. Tafani M, Cohn JA, Karpinich NO, Rothman RJ, Russo MA and Farber JL (2002) Regulation of intracellular $\mathrm{pH}$ mediates Bax activation in HeLa cells treated with staurosporine or tumor necrosis factor-alpha. J. Biol. Chem. 277: 49569-49576

60. Schinzel A, Kaufmann T, Schuler M, Martinalbo J, Grubb D and Borner C (2004) Conformational control of Bax localization and apoptotic activity by Pro168. J. Cell Biol. 164: 1021-1032

61. Khaled AR, Kim K, Hofmeister R, Muegge K and Durum SK (1999) Withdrawal of IL-7 induces Bax translocation from cytosol to mitochondria through a rise in intracellular pH. Proc. Natl. Acad. Sci. USA 96: 14476-14481

62. LeBlanc AC, Papadopoulos M, Belair C, Chu W, Crosato M, Powell J and Goodyer CG (1997) Processing of amyloid precursor protein in human primary neuron and astrocyte cultures. J. Neurochem. 68: 1183-1190

63. Zhang $Y$ and LeBlanc A (2002) Microinjections to study the specific role of proapoptotic proteins in neurons In Neuromethods Boulton AA and Baker GB (eds) (Totowa: Humana Press) pp. 83-106

64. Harlow E and Lane D (1999) Immunoprecipitation In Using Antibodies (New York: Cold Spring Harbor Laboratory Press) pp. 223-265

65. Eskes R, Antonsson B, Osen-Sand A, Montessuit S, Richter C, Sadoul R, Mazzei G, Nichols A and Martinou JC (1998) Bax-induced cytochrome C release from mitochondria is independent of the permeability transition pore but highly dependent on $\mathrm{Mg}^{2+}$ ions. J. Cell Biol. 143: 217-224

Supplementary Information accompanies the paper on Cell Death and Differentiation website (http://www.nature.com/cdd) 